\title{
Identifying the Effects of Place-Based Policies - Causal Evidence from Germany
}

\author{
Eva Dettmann \\ Matthias Brachert \\ Mirko Titze
}

CESIFO WORKING PAPER NO. 5901

CATEGORY 1: PUBLIC FinANCE

MAY 2016

An electronic version of the paper may be downloaded

- from the SSRN website:

wWw.SSRN.com

- from the RePEc website:

- from the CESifo website:

www.RePEc.org

www.CESifo-group.org/wp 


\title{
Identifying the Effects of Place-Based Policies - Causal Evidence from Germany
}

\begin{abstract}
The German government provides discretionary investment grants to structurally weak regions to reduce regional disparities. We use a regression discontinuity design that exploits an exogenous discrete jump in the probability of receiving investment grants, to identify the causal effects of the investment grant on regional outcomes. We find positive effects for regional gross value-added and productivity growth, but no effects for employment and gross wage growth.
\end{abstract}

JEL-Codes: Z000, A110, D610, H200.

Keywords: evaluation, industrial policy, regression discontinuity design.

Eva Dettmann*

Halle Institute for Economic Research (IWH)

Halle / Germany

Eva.Dettmann@iwh-halle.de

Matthias Brachert

Halle Institute for Economic Research

(IWH) / Halle / Germany

mbt@iwh-halle.de
Mirko Titze

Halle Institute for Economic Research

(IWH) / Halle / Germany

Mirko.Titze@iwh-halle.de

*corresponding author

April 2016

We are grateful to Steffen Mueller for numerous helpful comments on an earlier version of our paper. Moreover, we would like to thank the participants of the $8^{\text {th }}$ International Summer Conference in Regional Science in Kiel 2015, the 9th CESifo Workshop on Political Economy in Dresden 2015 and the 3rd Conference 'Geography of Innovation' in Toulouse 2016 for valuable discussions. Finally, we are indebted to Alexander Giebler and Michael Barkholz for preparing the data and the maps. 


\section{Introduction}

Place-based policies - commonly designed to increase employment and productivity, particularly in disadvantaged areas - are an integral part of the policy mix in many countries. In the United States, approximately USD 95 billion per year has been spent on place-based policies since the first decade of the 21st century (Kline and Moretti 2014a). The same holds true for the European Union (EU). Here, a significant fraction of the EU fiscal budget is handed out to member states via the Structural Funds, to support lagging regions. In the 2007-2013 programming period, expenditures amounted to $€ 278$ billion (i.e. $€ 39.7$ billion per annum, or $28 \%$ of the EU budget) (Ciani and de Blasio 2015).

The main goal of these place-based policies is to reduce inequalities, especially with respect to unemployment, income, and living conditions among regions. However, from an economic theory perspective, it remains questionable whether these policies work in the way they were originally intended (Glaeser and Gottlieb 2008, Kline and Moretti 2014b). On one hand, the presence of market failures with a spatial dimension may justify intervention. Moretti (2010) and Neumark and Simpson (2014) find agglomeration economies, spatial mismatch, network effects, or equity motivations as potential rationales that justify place-based policy schemes. On the other hand, the literature discusses the drawbacks of such interventions, all of which lead to nonproductive factor allocations. A first strand puts emphasis on the substitution process between production factors, even if the receipt of grants or tax premiums is tied to a single factor. An investment subsidy can, for example, reduce the marginal costs of physical capital and thus lead to a substitution of labour with capital due to a change in the relative factor prices, as well as an output effect where an outward production isoquant is reached. Even in the case of high substitution elasticities, the (negative) substitution effect may exceed the (positive) output effect. Consequently, the number of jobs in the region may decrease (Klodt 2000; Criscuolo et al. 2016). A second strand addresses potential displacement effects. In this case,

the increase, for example, in the number of jobs in a benefitting firm (region) comes at the expense of other firms (regions), whereas the net effect of the policy program 
may be zero. Such displacement effects are considered negative spillovers (Neumark and Simpson 2014).

This study contributes to the literature on the identification of causal effects of placebased policies. This is of importance because only reliable econometric evaluation studies that allow for the identification of causal effects can help clarify if and how place-based policies work, and for which policy schemes the results are promising (Criscuolo et al. 2012). This study investigates the most important long-term place-based policy scheme in Germany, the Joint Task for 'Improving the Regional Economic Structure' (GRW $\left.{ }^{1}\right)$. These discretionary investment grants are supposed to directly affect the production factor physical capital that influences the output figures of the production function. This allows us to explicitly address the impact channel of the program.

Compared to the previous literature, our study makes two novel contributions. First, as an analysis at the regional level, our study directly addresses firm-level GRW spillovers that are not captured by micro-level studies on firms and plants. By comparing output and employment growth rates, we can conclude whether substitution effects exceed the level effects for the whole economy in the treated regions. Second, the focus on one specific program through which the money is spent allows for a narrow interpretation of findings, in contrast to the broad evaluation of programs (such as the entire set of EU Structural Funds). Hence, the identification strategy enables us to directly address the causal effects of the GRW on specific regional outcomes.

Our dataset combines district-level panel data from West German regions with regards to eligibility, funding, and a set of regional controls. In line with the EU regional policy framework, we analyse the effects for two programming periodsnamely, 2000-2006 and 2007-2013. We address identification issues by adopting a quasi-experimental research design that uses exogenously determined discontinuities in the regions' eligibility to receive investment grants. Leveraging a regression discontinuity design (RDD), we compare regions that lie closely on either side of

\footnotetext{
${ }^{1} \mathrm{GRW}$ is the acronym used in this paper with reference to this instrument. The full German term is as follows: Gemeinschaftsaufgabe 'Verbesserung der Regionalen Wirtschaftsstruktur'.
} 
the eligibility cut-off value, to estimate the causal effect of the GRW. Our analysis focuses on growth in the central components of the production function: output (gross value-added [GVA], productivity [GVA per worker]) and labour (number of employees, and gross wages and salaries). ${ }^{2}$

We find positive effects of the GRW on regional GVA and productivity growth, but no effect on the growth of regional employment and gross wages in the 2000 2006 programming period. For the 2007-2013 period, we find no GRW effect. We consider this result a direct consequence of the global financial crisis that took place during this period. Like most countries, Germany enacted very large schemes in support of firms, banks, and households to stabilize the economy during the crisis; this may have made it more difficult to identify the GRW effects during that period.

The rest of this paper is organized as follows. The next section presents a brief literature overview of empirical findings concerning the effectiveness of regional policy schemes. Section 3 describes the GRW design in greater detail and presents an identification strategy that allows for the application of an RDD to identify the causal effects of the GRW on different area-level outcomes. In section 4, we present our data and selected descriptive statistics. Section 5 discusses the main results of the regression analysis and gives a 'back of the envelope' calculation of the net effect of GRW. Section 6 concludes the paper.

\section{Review of the empirical literature}

Place-based policies comprise a variety of measures, ranging from those that focus on enterprise zones (Neumark and Kolko 2010, Mayer et al. 2015), cluster policies (Falck et al. 2010, Martin et al. 2011), or large-scale regional development programs such as the Tennessee Valley Authority (Kline and Moretti 2014b). We restrict our review of the literature to evaluation studies of discretionary investment grantbased policy schemes that are comparable to the GRW; examples include Italy's Law 488/1992 and the United Kingdom's 'Regional Selective Assistance' (RSA)

\footnotetext{
${ }^{2}$ We cannot analyse the effects of the GRW on the stock of physical capital, since German official statistics do not provide data on regional capital stock or regional investment activities.
} 
program, both of which provide investment grants to firms in lagging regions, and major infrastructure investments made under the EU regional policy scheme.

\subsection{Studies at the level of plants/establishments}

Similar to the GRW, Italy's Law 488/1992 grants public subsidies to firms willing to invest in disadvantaged regions. The firm-level effects of this program have been identified in various ways. Bernini and Pellegrini (2011) evaluate the effects of the policy by combining plant-level data and information on subsidy allocation for the 1996-2004 period. Using a matching and difference-in-difference approach, they find there to be positive short-run effects on output, employment, and investment, but negative long-run effects on productivity. Bronzini and de Blasio (2006) evaluate Law 488/1992 by comparing supported and rejected projects between 1993 and 2001. They confirm a positive effect on investments, but present evidence for intertemporal substitution, given the time restriction of the programming period. Cerqua and Pellegrini (2014) leverage the unique Law 488/1992 selection process to develop an RDD where the treatment is assigned through multiple rankings with different cut-off points. While this allows them to identify the positive effects of this policy scheme on employment, investment, and turnover, the effects on productivity remain negligible. Unlike Bronzini and de Blasio (2006), they find their results to be robust against intertemporal substitution. Pellegrini and Cetra (2006) further focus on the effects of Law 488/1992 on plants in the Mezzogiorno region; they identify on average a positive effect of funding on sales, employment, and fixed assets. As in the aforementioned studies, the effect on factor productivity (in this case, labour) remains very limited, and even negative.

Similar to the GRW and Law 488/1992, the United Kingdom's RSA program provides discretionary grants to firms in disadvantaged regions. Devereux et al. (2007) present micro-economic evidence of the effects of the RSA on firm location decisions. Their results indicate small positive and significant RSA effects on the location choice of new entrants. Criscuolo et al. (2016) analyse the effectiveness of the RSA using administrative data, in combination with firm-level data, for the 1986-2004

period. Applying an instrumental variable (IV) approach, they find positive RSA 
effects on employment and investment at the firm level, but no program effect on factor productivity. When differentiating the effects by firm size, they show that small and medium-sized firms experience the strongest effects, while the effect for large firms is almost zero.

Causal evaluation studies addressing the establishment-level effects of the GRW in Germany were conducted by Stierwald and Wiemers (2003). Using data from the establishment panel of the Institute of Employment Research for the 20002002 period, they find a positive GRW effect on the amount of investment per employee and on sales among East German establishments. The study of Bade and Alm (2010) applies a matching with difference-in-difference approach. For firms supported during the 2001-2006 period, they report a positive effect on employment growth from the year of funding to 2008. ${ }^{3}$ The findings of Bade and Alm (2010) with regards to the GRW suggest a decline in regional employment in the eligible sectors within the period under analysis; these findings suggest potential intraregional displacement effects. ${ }^{4}$ However, the only way to study overall intra-regional displacement effects is to conduct regional-level studies.

\subsection{Studies at the regional level}

Regional-level evaluation studies are effective in considering the spatialities of placebased policies. However, they remain rare in empirical research. In a joint evaluation of the effects of Law 488/1992 and the Contratti di Programma, de Castris and Pellegrini (2012) develop a spatial difference-in-difference model to confirm that this policy had a net positive employment impact in the 1996-2001 period. While their results indicate a modest spatial 'crowding out' with subsidized regions attracting employment from neighbouring regions, the increase in the number of employees in the subsidized regions exceeds those in the other regions. Criscuolo et al. (2016) present area-level findings regarding the RSA. With the help of their IV approach,

\footnotetext{
${ }^{3}$ In a further study, Bade (2013) differentiates the GRW effect by firm size and finds stronger employment effects for larger establishments.

${ }^{4}$ Bade and Alm (2010) apply a two-step matching procedure: exact matching and propensity score matching. One variable used in the exact matching is the location in the same region. In other words, treated firms and comparable nontreated firms need to be located in the same area.
} 
they exploit changes in the area-specific eligibility criteria. They demonstrate that the RSA caused an increase in regional employment that is not due to displacement effects between eligible and non-eligible regions. Moreover, that study confirms the positive effects on net firm entry and firm investment, and no effects on total factor productivity.

Further insights on area-level outcomes of place-based policies can be found in Becker et al. (2010), who analyse the causal effects of EU Structural Funds on regional performance measures. With the help of an RDD, Becker et al. (2010) find positive effects of the EU Structural Funds on GDP per capita growth, but no employment growth effects. A subsequent study by Becker et al. (2012) using generalized propensity score methods demonstrates that EU transfers enable faster growth in the recipient regions, but that for quite a number of regions, a reduction of transfers would not contribute to growth reduction. Finally, Becker et al. (2013) highlight that the effect identified in the RDD design is highly heterogeneous across regions and strongly depends on a region's absorptive capacity, measured in terms of human capital and the quality of institutions.

The first study to address the area-level outcomes of place-based policies in Germany was undertaken by von Ehrlich and Seidel (2015). They investigate the effects of a support scheme that assisted West German regions situated close to the border of the former German Democratic Republic and Czechoslovakia (the so-called Zonenrandgebiet [ZRG]). This complex aid scheme (which was applied between 1971 and 1994) consisted of five different program-supported targets: i) regional economic activities, ii) public transport infrastructures, iii) housing, iv) social housing and daycare centres, and v) education and cultural activities. Financial resources within this program were drawn from tax premiums and grants. Using a spatial RDD, the authors find small net effects of this policy scheme on regional outcomes. Although the GRW was part of the ZRG program family, the analysis of von Ehrlich and Seidel (2015) draws no direct conclusions on the effects of this program. Similar to the studies of Becker et al. (2010, 2012, 2013), the complex nature of the ZRG and EU Structural Funds does not allow for the derivation of any direct conclusions regarding the effects of specific elements of these policy mixes. Therefore, a discrete analysis of GRW is crucial, as this program was assigned not only to ZRG areas, 
but also to a considerable number of regions outside this area. (See the maps in Figure 7 of the Appendix.)

The need for an in-depth analysis of the specific elements of complex major policy measures serves as the rationale for our empirical study. As we were able to access detailed administrative data on the allocation scheme and the absorption of funds, we are able to estimate the causal effect of the GRW on various regional outcomes. Furthermore, in contrast to broad evaluations of programs - such as the entire set of EU Structural Funds, or the entire ZRG support scheme-we are capable to interpret our findings in a narrower sense.

\section{$3 \quad$ Institutional details and identification strategy}

\subsection{Institutional details}

Within the Joint Task for 'Improving Regional Economic Structures', ${ }^{5}$ the German government ${ }^{6}$ provides subsidies for the investment projects of firms and municipalities in structurally weak regions. In the $1991-2013$ period, $€ 67.7$ billion were spent under this program. A significant share of these expenditures was issued in the aftermath of German reunification, since the East German regions in particular suffered from a period of deindustrialization. The main thrust of this instrument was to reduce spatial disparities between regions within Germany. In 1991, the overall yearly GRW budget was about $€ 5.9$ billion; this amount decreased to about $€ 1.3$ billion in 2013 (BAFA 2015).

Eligible regions within the GRW framework were selected according to a composite score calculated at the labour market regional level. It consists of a (weighted) combination of four single indicators of structural weakness (i.e. the average unemployment rate, annual gross salaries, an employment projection, and the quality of

\footnotetext{
${ }^{5}$ The operationalization of the program relies on a specific law (GRW-law, Bundesregierung 1969).

${ }^{6}$ In Germany, regional policy remains the responsibility of the federal states (Article 30 of German Basic Law). However, the constitution permits the Federation's support of the federal states in establishing, implementing, and funding regional policy schemes.
} 
business-oriented infrastructure), all of which were measured prior to the start of the respective programming period (Schwengler and Binder 2006). The eligibility status of a region is nonetheless defined at the level of districts and district-free cities. Districts within the same labour market region all obtain the same scores. The number of GRW-assisted regions is restricted according to the EU legislatives. For each programming period, the EU fixes an arbitrarily defined limit for the overall population of the assisted regions, in relation to the population within the EU 25 member states. The general share is broken down across the member states. In Germany, $40.7 \%$ of the overall population lived in assisted regions in the 2000-2006 programming period, and $40.2 \%$ in the subsequent 2007-2013 period (Schwengler and Binder 2006; coordination frameworks [see Table 11 of the Appendix]).

Our analysis covers West German regions in the 2000-2006 and 2007-2013 programming periods. ${ }^{7}$ Figure 1 shows all 325 West German regions ranked by their respective scores, in ascending order. ${ }^{8}$ The first region in this ranking list that is formally not eligible reflects the implementation of the exogenous population threshold of the EU. All regions with a score below this threshold are formally eligible (i.e. on the left-hand side of the red lines in Figure 1).

As Figure 1 indicates, the score follows a very smooth trend at this cut-off value.

\footnotetext{
${ }^{7}$ An analysis of Germany overall is not possible within this research design. In the 2000-2006 period, composite scores are calculated separately for West and East Germany (including Berlin). For the 2007-2013 period, a score was determined for Germany overall, but between 2006 and 2011, three of five East German federal states (i.e. Saxony, Saxony-Anhalt, and MecklenburgVorpommern) set up administrative territorial reforms. Given that the score is calculated before the programming period starts, in the three aforementioned federal states, the scores rely on a territorial classification that cannot be merged with the treatment status of the regions (which builds on the new classification scheme).

${ }^{8}$ The actual eligibility status is reported in the annually published Coordination Frameworks (volumes 29-37) edited by the German parliament (see also Table 11 of the Appendix for details). Statistics on annual GRW grants at the regional level are provided by the German Federal Office for Economic Affairs and Export Control (BAFA). The score values for the 2000-2006 programming period are taken from Koller et al. (2000), and those for the 2007-2013 period from Eckey (2008).
} 


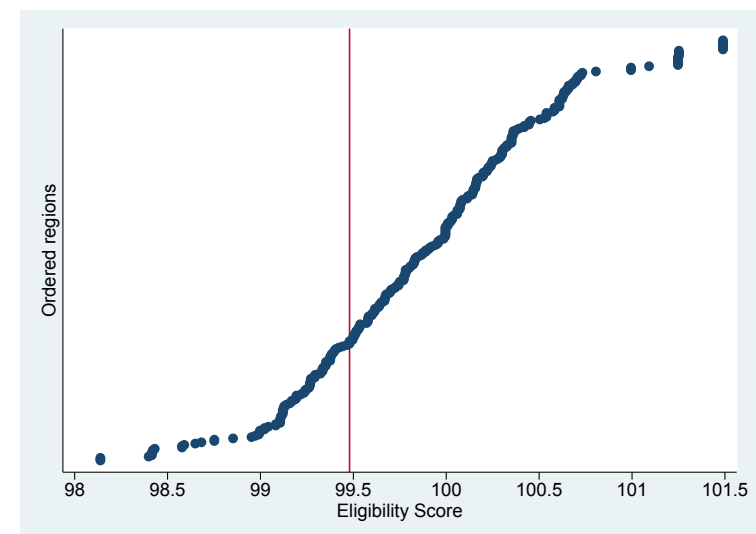

2000-2006 programming period

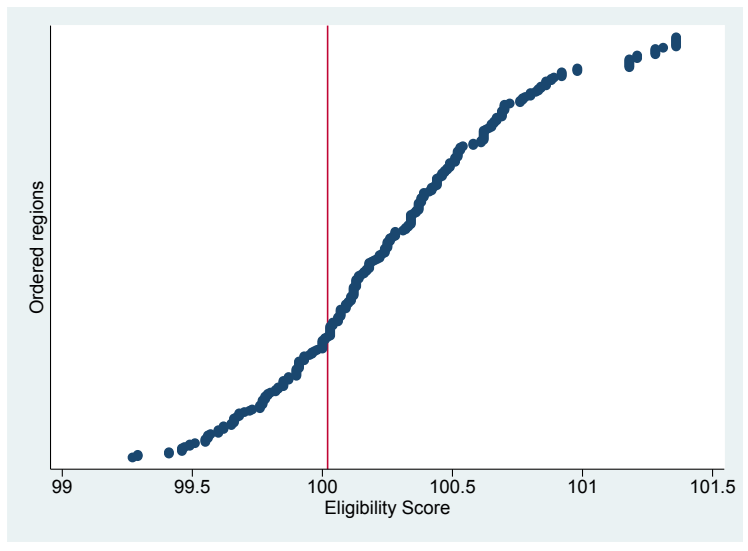

2007-2013 programming period

Figure 1: Slope of the eligibility score and the first noneligible region

Note: The vertical red line represents the score of the 'last' eligible region. The next region in this ranking is the first region that is not eligible for GRW grants.

Sources: 2000-2006 scores: Koller et al. (2000); 2007-2013 scores: Eckey (2008); formal eligibility status: coordination frameworks (see Table 11 of the Appendix). Own illustration.

Figure 2 compares the eligibility status to the treatment status, the receipt of investment grants in the respective programming period. The dots represent the average treatment rates of regions with similar values of the eligibility score, namely values in equally sized bins of 0.05 . The vertical red line represents the implemented EU population coverage limit. If we would have a perfect connection between eligibility and treatment status, we would observe two lines: left of the cut-off, the treatment rate would be one, and zero at the right hand side. But we observe regions where firms and municipalities do not receive grants despite the low score of the region (left of the cut-off value), and we find regions where firms and municipalities receive money although the region is not assigned to treatment (right of the cut-off; see Table 11 of the Appendix for details).

Nevertheless, we observe a considerable jump in the treatment status in both periods under analysis. This finding gives rise to the use of an RDD for evaluation purposes. 


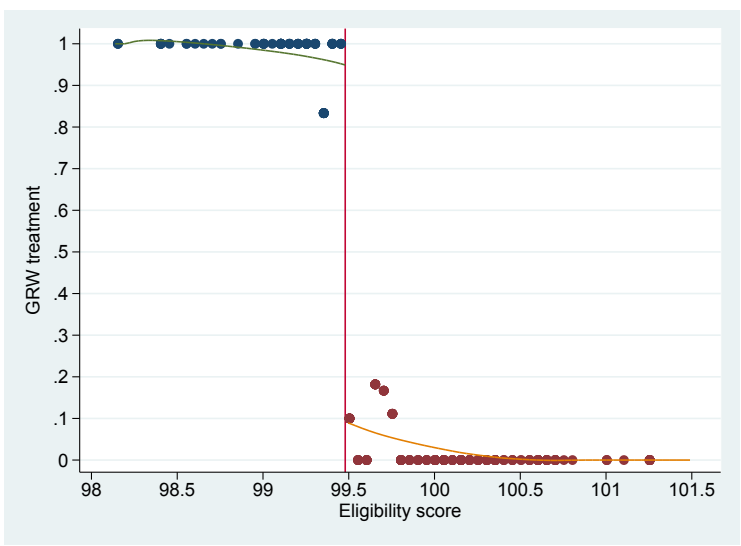

2000-2006 programming period

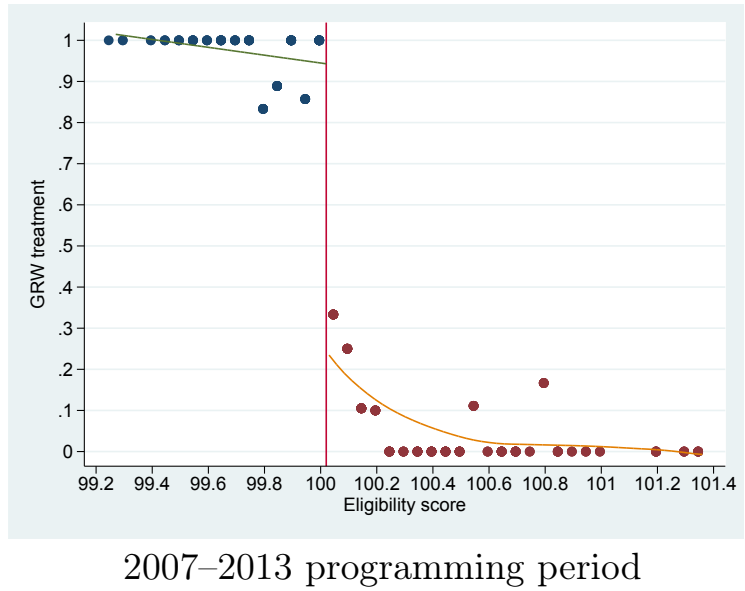

2007-2013 programming period

Figure 2: Treatment and assignment status

Note: The figure shows the average treatment rates in equally sized bins of 0.05 . The fitted lines represent a local polynomial smoothing of the treatment rates based on an Epanechnikov kernel with rule-of-thumb bandwidth.

Sources: 2000-2006 scores: Koller et al. (2000); 2007-2013 scores: Eckey (2008); treatment status: BAFA (2015). Own calculations and illustration.

Exceptions to the treatment are made by a Coordination Committee ${ }^{9}$ that comprises part of the program's legal framework. Deviations from the general rule are justified with very localized constraints not observable at the labour market regional level. One typical example of such an exception is the district Gifhorn, which belongs to the labour market region of Wolfsburg. The company headquarters and chief administrative offices of Volkswagen are located in the district Wolfsburg; consequently, the score value of the labour market region of Wolfsburg, as reported in Eckey (2008), is relatively high for both districts belonging to that region. Despite their equal score, districts within the region very much differ. As a result, the Coordination Committee decided that Gifhorn can be treated under the GRW framework. The spatial allocation of the different regional types is presented in two maps in Figure 7 of the Appendix. The general rule regarding the population share is not affected by these decisions. Against this backdrop, we use a fuzzy RDD design.

\footnotetext{
${ }^{9}$ The Committee members agree on the general rules for the provision of investment grants (e.g. the definition and calculation of the score).
} 


\subsection{Identification strategy}

The key elements of the RDD are an exogenous cut-off value -in our study the EU population coverage limit-, a jump in the treatment rate at this cut-off, and a smooth forcing variable, here the eligibility score. The crucial question is whether the assignment is exogenous. In the current case, the assignment status of each region consists of two elements - namely, the population coverage limit of the EU, and the eligibility score under the GRW. It is obvious that the population limit cannot be influenced by a single firm or district. Regarding the second element, Lee and Lemieux (2010) argue that with an RDD, the assumption of exogeneity is fulfilled - at least in the vicinity of the cut-off value - if the actors have imprecise control over the forcing variable. This means that in our study, we need to ensure that it is not possible for GRW-receiving regions to influence the eligibility score. This assumption is assumed to hold, for three reasons. First, the score is defined at the labour market regional level (which consists of comparatively large areas), and not at the district level. Second, it consists of four indicators that measure each labour market region's degree of structural weakness. All of these indicators are beyond the control of a single actor. Third, these indicators are measured at different time points prior to the programming period. For these reasons, we assume the assignment to be exogenous for the actors.

Additionally, Figure 3 presents a density test for the eligibility score. The thinking behind the test of McCrary (2008) is that if manipulation were possible, we should observe a density jump at the cut-off value. In our study, the density on the lefthand side should be much higher. For both programming periods, however, we observe no higher densities to the left of the cut-off value. The density difference at the cut-off value is -0.09 for the first programming period, and 0.3 for the second one. It is insignificant in both cases.

Given the exogeneity of the score and the nondeterministic relationship between the score and the treatment, we estimate the treatment effect within a fuzzy RDD framework. We use the following model:

$$
y_{i}=\alpha_{0}+\tau D_{i}+f(x)+u_{i}
$$




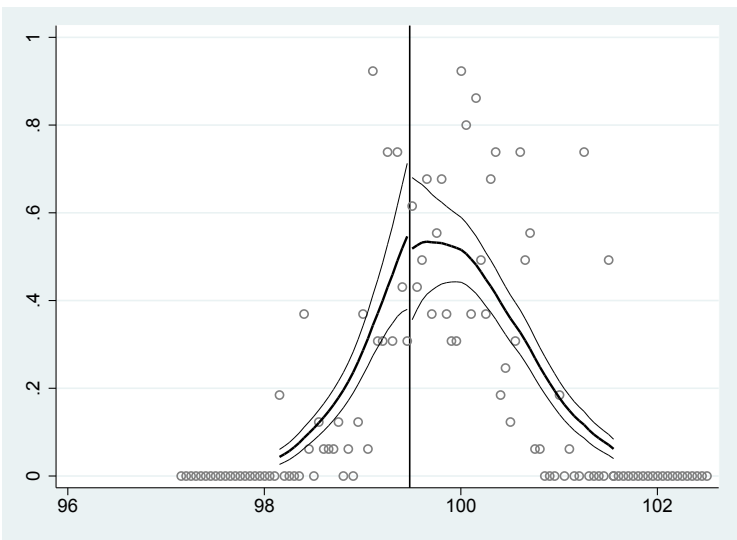

2000-2006 programming period

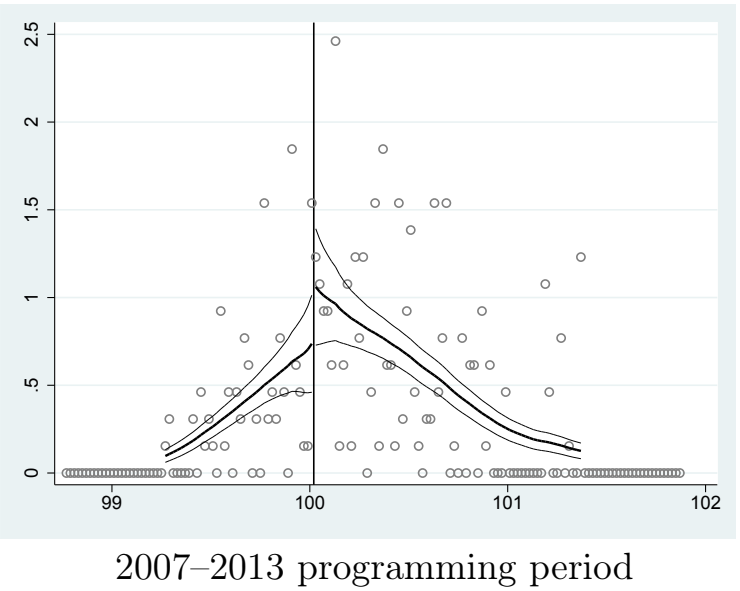

2007-2013 programming period

Figure 3: McCrary density test of the eligibility score

Sources: 2000-2006 scores: Koller et al. (2000); 2007-2013 scores: Eckey (2008). Own calculations and illustration.

where $\tau$ is the parameter of interest and $D_{i}$ denotes the treatment status of region i. The function $f(x)$ is a polynomial function of the eligibility score. We apply a model without constraints - that is to say, we allow for different functional forms to the left and right of the cut-off: $f(x)=\beta_{0}\left(x_{i}-x_{c}\right)+\delta D_{i}\left(x_{i}-x_{c}\right) \cdot{ }^{10}$

Within a fuzzy RDD, estimations of an ordinary least squares (OLS) regression in refeq:outcomerdd would be biased (Imbens and Lemieux 2008). Hahn et al. (2001) first showed the connection between a fuzzy RDD and the IV approach, and suggested the use of a two-stage least squares regression (TSLS). We follow this approach and estimate IV instead of OLS, where treatment is instrumented by the assignment status $Z_{i}$ :

$$
D_{i}=\eta+\gamma Z_{i}+f(x)+\varphi_{i}
$$

This TSLS can be estimated by applying the usual heteroskedasticity-robust IV standard error terms (Imbens and Lemieux 2008, Wooldridge 2010). The estimator of $\tau$ in equation 1 can be interpreted as the local average treatment effect (Hahn et al. 2001).

\footnotetext{
${ }^{10}$ Constraining the functions to be the same on both sides of the cut-off value would mean using data from the left-hand side to estimate the parameters for the right-hand side, and vice versa. Clearly, doing so would be 'inconsistent with the spirit of the RD design' (Lee and Lemieux 2010, p. 318). However, Angrist and Pischke (2009) state that estimating the restricted function and the more flexible one yield very similar results. For both functions, we use $\left(x_{i}-x_{c}\right)$ instead of the eligibility score value itself to capture the treatment effect at the cut-off point (Angrist and Pischke 2009).
} 


\section{Data: Sources and descriptive statistics}

\subsection{Treatment and outcomes}

Our dataset comprises the 2000-2013 period (i.e. two full programming periods). Table 1 depicts average annual figures with respect to GRW funding received by West German regions.

Table 1: Average annual amount of GRW subsidies

\begin{tabular}{ccccc}
\hline \hline & $\begin{array}{c}\text { GRW per region } \\
(€ \text { Millions })\end{array}$ & $\begin{array}{c}\text { GRW per capita, per region } \\
(€)\end{array}$ & $\begin{array}{c}\text { total GRW } \\
(€ \text { Millions })\end{array}$ & $\begin{array}{c}\text { treated } \\
\text { regions }\end{array}$ \\
\hline $2000-2006$ & 3.1 & 135.2 & 295.6 & 96 \\
$2007-2013$ & 2.6 & 134.0 & 272.8 & 105 \\
\hline \hline
\end{tabular}

Sources: Raw data: BAFA (2015). Own calculations.

Regarding the 2000-2006 programming period, the average annual amount of GRW subsidies is $€ 295.6$ million for all West German regions, and $€ 3.1$ million per region. The figures are slightly lower in the subsequent programming period.

Our study focuses on four outcomes: i) GVA, ii) productivity (GVA per employee), iii) regional employment, and iv) gross wages and salaries. These data are provided by the German statistical offices of the Federation and the various federal states. Table 2 compares the mean outcomes of the treated regions with those of the nontreated regions.

The mean level values of all four outcome variables for the years 2000 and 2007 are higher in the nontreated regions than in the treated ones. The mean growth rates of employment, personal income, and output are also - at least slightly - higher in the nontreated regions. This finding holds true for both periods under analysis. One exception is productivity, which increases more strongly in the treated regions in the 2007-2013 period. However, a look at the minimum and maximum values reveals that there is much variation inside the groups. 
Table 2: Descriptive statistics of the outcomes

\begin{tabular}{|c|c|c|c|c|c|c|}
\hline & \multicolumn{3}{|c|}{ Nontreated regions } & \multicolumn{3}{|c|}{ Treated regions } \\
\hline & Mean & Min & Max & Mean & Min & $\operatorname{Max}$ \\
\hline \multicolumn{7}{|c|}{ Level values 2000} \\
\hline Employment $^{(1)}$ & 109.06 & 20.50 & 1048.90 & 76.25 & 20.03 & 332.17 \\
\hline Wage sum ${ }^{(2)}$ & 2603.89 & 447.09 & 28367.16 & 1648.03 & 332.25 & 7897.87 \\
\hline $\mathrm{GVA}^{(2)}$ & 5673.67 & 959.33 & 70132.19 & 3350.87 & 742.17 & 17631.77 \\
\hline Productivity ${ }^{(3)}$ & 47.72 & 36.58 & 97.77 & 42.68 & 33.67 & 56.62 \\
\hline \multicolumn{7}{|c|}{ Period growth rate, 2000-2006 } \\
\hline Employment & 0.008 & -0.097 & 0.122 & -0.021 & -0.133 & 0.097 \\
\hline Wage sum & 0.060 & -0.069 & 0.265 & 0.008 & -0.222 & 0.142 \\
\hline GVA & 0.144 & -0.067 & 0.521 & 0.107 & -0.092 & 0.359 \\
\hline Productivity & 0.135 & -0.057 & 0.440 & 0.132 & -0.028 & 0.375 \\
\hline Observations & \multicolumn{3}{|c|}{229} & \multicolumn{3}{|c|}{96} \\
\hline \multicolumn{7}{|c|}{ Level values 2007} \\
\hline Employment $^{(1)}$ & 113.27 & 19.75 & 1084.95 & 75.89 & 19.29 & 339.92 \\
\hline Wage $\operatorname{sum}^{(2)}$ & 2901.72 & 470.48 & 31930.47 & 1725.41 & 347.40 & 8590.41 \\
\hline $\mathrm{GVA}^{(2)}$ & 6903.00 & 1069.51 & 82939.42 & 3876.53 & 843.35 & 21521.82 \\
\hline Productivity ${ }^{(3)}$ & 55.72 & 39.61 & 112.18 & 49.27 & 38.92 & 63.31 \\
\hline \multicolumn{7}{|c|}{ Period growth rate, 2007-2013 } \\
\hline Employment & 0.056 & -0.038 & 0.270 & 0.036 & -0.055 & 0.170 \\
\hline Wage sum & 0.201 & 0.051 & 0.562 & 0.177 & -0.029 & 0.525 \\
\hline GVA & 0.138 & -0.097 & 0.712 & 0.122 & -0.124 & 0.286 \\
\hline Productivity & 0.078 & -0.148 & 0.493 & 0.083 & -0.130 & 0.220 \\
\hline Observations & \multicolumn{3}{|c|}{220} & \multicolumn{3}{|c|}{105} \\
\hline
\end{tabular}

Notes: ${ }^{(1)}$ Number of employed persons, in thousands; ${ }^{(2)} €$ Millions; ${ }^{(3)}$ GVA per employee, in $€$ Thousands.

Sources: Statistical offices of the Federation and the various federal states; BBSR and BA.

To gain insights into the causal effects of the GRW within an RDD framework, we compare the outcomes near the cut-off value. A first description of the mentioned outcomes is presented in Figures 4 and 5. The Figures show the averages of the period growth rates in equally sized bins of 0.05. Dots represent regions where assignment and treatment status are equal; crosses mark regions where treatment and assignment status differ. The fitted lines represent the estimated trend functions of the growth rates of the eligible treated regions (on the left) and the noneligible, nontreated regions (on the right)—or, in other words, the dots in both figures. 

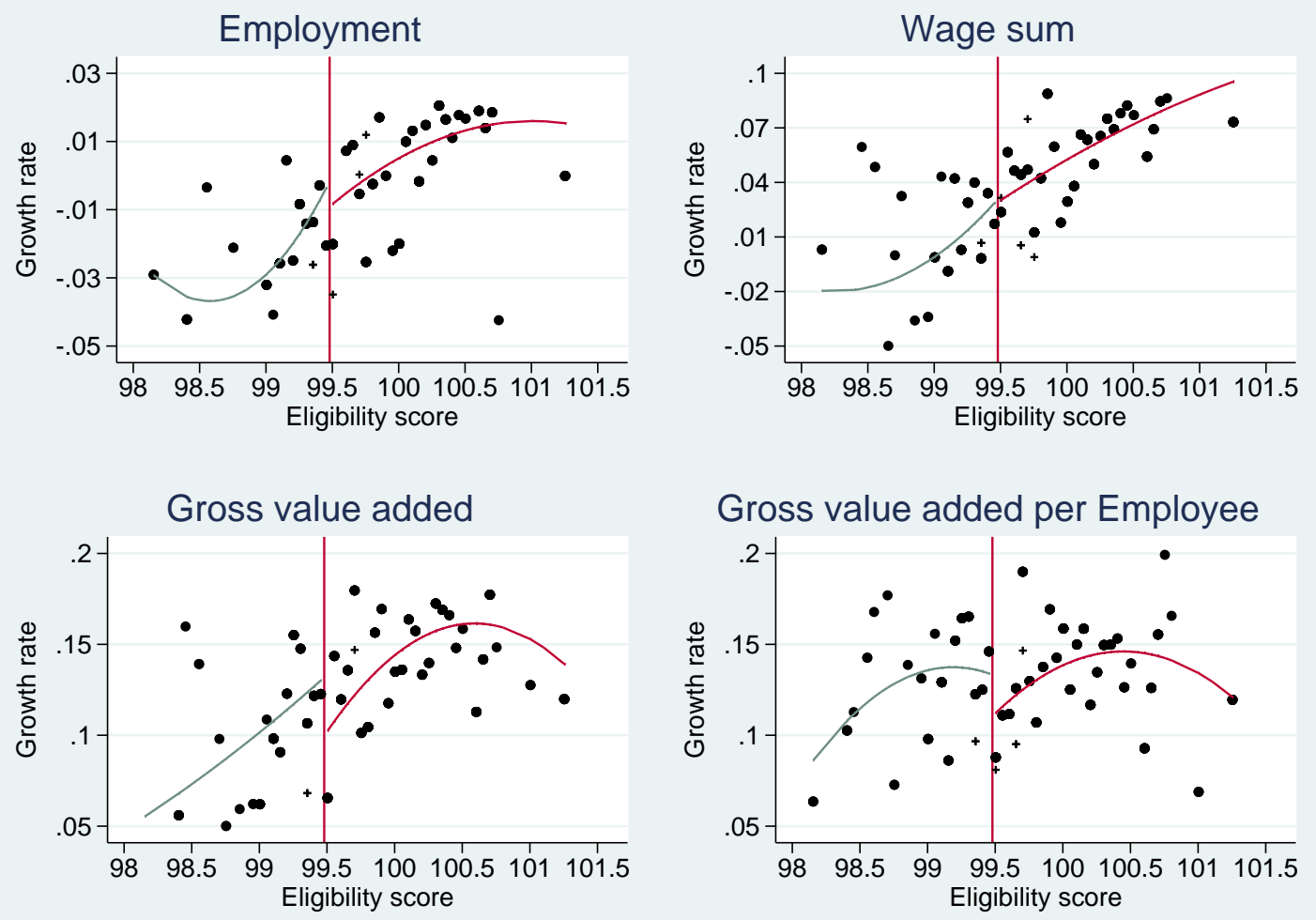

Figure 4: Growth rates of regions near the cut-off (2000-2006 programming period)

Note: The figure shows averages of the period growth rates in equally sized bins of 0.05 ; dots: assignment $=$ treatment; crosses: assignment $\neq$ treatment. The fitted lines represent 3rd-order polynomials of the dots.

Sources: Statistical offices of the Federation and the various federal states; scores: Koller et al. (2000); treatment status: BAFA (2015). Own calculations and illustration.

For the 2000-2006 programming period (Figure 4), we observe gaps at the cut-off value for regional output and productivity growth. The lines are slightly higher on the left side, suggesting the positive influence of investment subsidies for these two outcomes. Neither of the other two graphs reveals a jump at the cut-off value, indicating that regional investment subsidies have no effect on either outcome variable.

For the second programming period (2007-2013; Figure 5), we see another picture: for growth in regional employment and regional personal income, the effect is potentially positive, but for output and productivity growth, the graphs suggest a negative effect. 

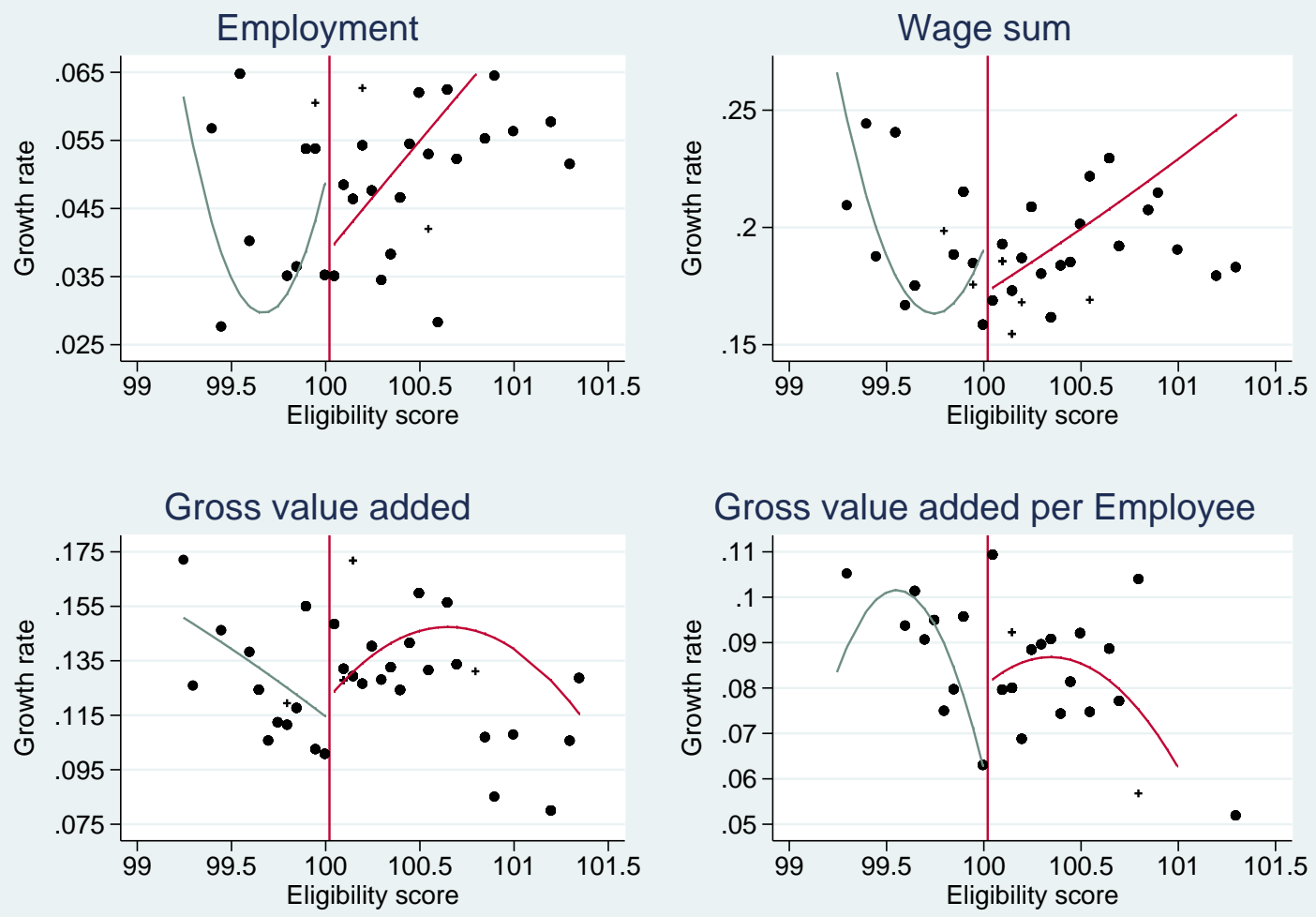

Figure 5: Growth rates of regions near the cut-off value (2007-2013 programming period)

Note: The figure shows averages of the period growth rates in equally sized bins of 0.05 ; dots: assigned $=$ treatment; crosses: assigned $\neq$ treatment. The fitted lines represent the 3rd-order polynomials of the dots.

Sources: Statistical offices of the Federation and the various federal states; scores: Eckey (2008); treatment status: BAFA (2015). Own calculations and illustration.

In section 5.1, we examine whether these gaps are indicative of significant treatment effects; we also discuss reasons as to why the effects differ between these periods. However, before we enter this debate, we take a deeper look at potential and prevalent differences across those regions in the vicinity of the cut-off value.

\subsection{Control variables}

It might be the case that regional characteristics exert an influence on the assignment status of a region, and would bias the estimated effects.

We consider i) a set of controls typically recognized as indicators of the level of regional economic development: the rate of employment, and gross wages per em- 
ployee. Data on both variables are available through the database 'Indicators, Maps and Graphics on Spatial and Urban Monitoring' (INKAR). Another set of controls ii) is associated with the regional endowment of production factors - namely, the quality of infrastructure (INKAR); the share of highly qualified employees, as a proxy for human capital (statistics of the German Federal Employment Agency [BA]); and migration as a proxy for future work force (INKAR). A last set iii) of variables addresses sector-based structures and issues relating to agglomeration economies. Within this category of controls we take into account that some industries are excluded from receiving investment subsidies, as per the EU legislatives. This mainly applies to the industries in the primary sector, but also to selected industries in the manufacturing (e.g. chemical fibres, shipbuilding, etc.) and service sectors. Therefore, we control for the share of employment in the eligible sectors in a region. Information on the eligibility of industries is provided by the German Federal Office for Economic Affairs and Export Control (BAFA). Data on employment by sector are taken from the BA dataset. We address issues relating to agglomeration economies by considering regional specialization, which is measured with the help of the Herfindahl Index. This indicator is calculated at the level of divisions within the manufacturing section $\mathrm{C}$ (two-digit level, including the share of each division number in the range from 15 to 37 of the Classification of Economic Activities, Edition 2003 [WZ 2003] within total manufacturing employment). ${ }^{11}$ Data are drawn from the BA dataset. Finally, we consider the population density (INKAR).

We observe all regional variables for the year before treatment starts (i.e. 1999 and 2006 for the 2000-2006 and 2007-2013 programming periods, respectively) and mean values for three years before treatment. Table 8 of the Appendix contains the descriptive statistics for all control variables one year prior treatment.

\footnotetext{
${ }^{11}$ Specialization is measured for industries in the manufacturing sector, because the proverbial lion's share of GRW grants is allocated to this sector. This does not imply that this instrument is solely addressed to the manufacturing sector; quite the contrary: investment subsidies within the GRW framework are not restricted to any specific industry. The eligibility requirement is the criterion of 'supra-regional sales': the applying firm must sell its goods or services beyond a $50-\mathrm{km}$ radius of the production location. This characteristic is also fulfilled by many service sector industries. Nevertheless, the number and amount of investment projects in the manufacturing sector are larger than those of the service sector.
} 
First, we check whether these control variables follow a 'smooth' trend at the cutoff. Any jumps at the cut-off value would cast doubt on the credibility of our identification strategy (Becker et al. 2010). Figure 6 report control values for the respective year prior to the programming period (i.e. 1999 and 2006), summarized in equally sized bins of 0.05 . The fitted lines represent 3rd-order polynomials. ${ }^{12}$

In general, we observe at the cut-off value a smooth trend for the control variables. Exceptions are the variables population density in the first programming period and both wage per employee and human capital in the second period. However, as with the outcomes, we need to analyse whether these differences are significantly different from zero (see section 5.4). Descriptive statistics for all control variables one year prior to treatment are included in Table 8 of the Appendix.

\footnotetext{
${ }^{12}$ The mean control values for the three years before treatment starts (1997-1999 and 2004-2006, respectively) yield very similar figures.
} 

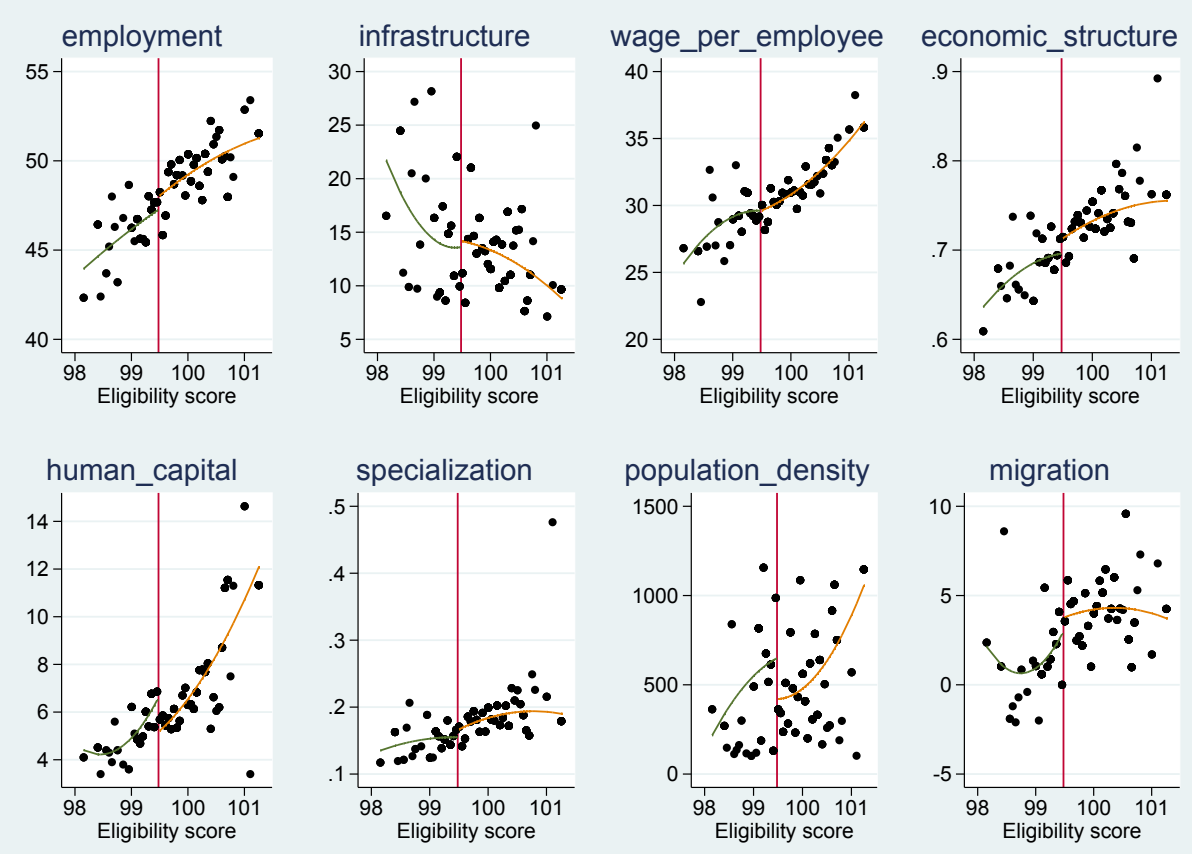

2000-2006 programming period
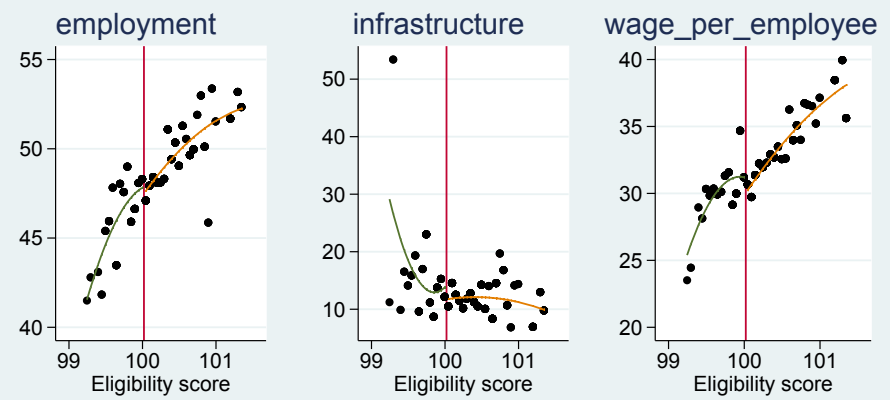

economic_structure
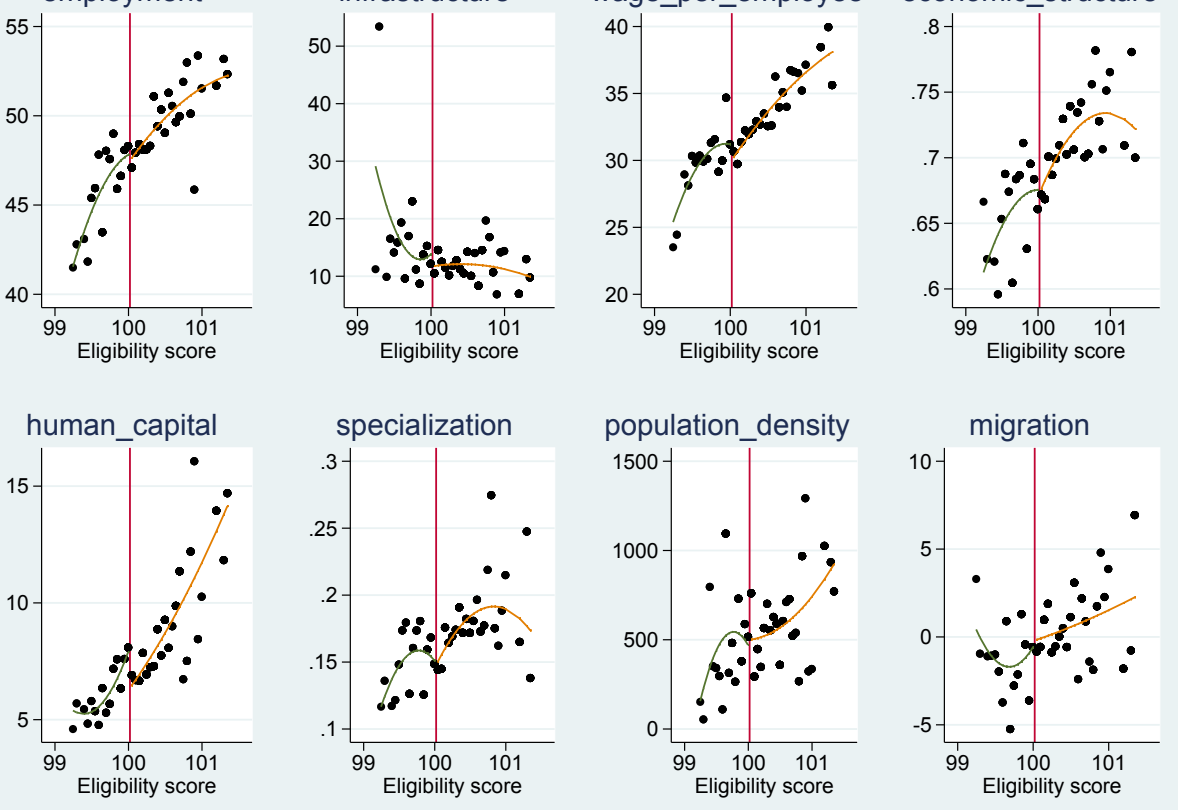

2007-2013 programming period

Figure 6: Control variables near the cut-off value

Notes: control values one year before treatment; dots are average values of bins of size 0.05 ; fitted lines are 3rd-order polynomials of the dots.

Sources: scores: Koller et al. (2000); treatment status: BAFA (2015); regional controls: INKAR dataset, German Federal Employment Office. Own calculations. 


\section{Results}

\subsection{Effects of the GRW}

To identify the causal effect of the GRW on regional development, we estimate the IV model for the period growth rates for the two programming periods (i.e. 2000-2006 and 2007-2013). The presented results are based on 3rd-order polynomials (Table 3$).{ }^{13}$ For the first programming period, our estimates show a positive treatment effect on output in terms of GVA and productivity (GVA per employee). For the second programming period, we observe no significant GRW effect whatsoever. Our findings for the 2000-2006 period align with the theoretical considerations

Table 3: Estimation results

\begin{tabular}{lcccc}
\hline \hline & Employment & Wage sum & GVA & GVA/employee \\
\hline \multirow{3}{*}{ Treatment } & \multicolumn{2}{c}{ 2000-2006 programming period } & \\
& -0.00444 & -0.0183 & $0.0514^{* *}$ & $0.0561^{* * *}$ \\
Constant & $(0.0130)$ & $(0.0169)$ & $(0.0222)$ & $(0.0174)$ \\
& -0.00667 & $0.0387^{* * *}$ & $0.0839^{* * *}$ & $0.0912^{* * *}$ \\
& $(0.0102)$ & $(0.0126)$ & $(0.0164)$ & $(0.0127)$ \\
\hline adjusted $R^{2}$ & 0.146 & 0.225 & 0.0756 & 0.0139 \\
\hline \multirow{2}{*}{ Treatment } & $200^{\text {r-2013 }}$ & programming period & \\
Constant & 0.0225 & 0.0301 & -0.00496 & -0.0274 \\
& $(0.0150)$ & $(0.0296)$ & $(0.0319)$ & $(0.0252)$ \\
\hline adjusted $R^{2}$ & $0.0278^{* * *}$ & $0.156^{* * *}$ & $0.123^{* * *}$ & $0.0922^{* * *}$ \\
\hline \hline
\end{tabular}

Robust standard errors in parentheses; significance level: ${ }^{* * *} \mathrm{p}<0.01,{ }^{* *} \mathrm{p}<0.05,{ }^{*} \mathrm{p}<0.1$

Model specification: 3rd-order polynomial of the eligibility score; no constraints (coefficients omitted).

Sources: Statistical offices of the Federation and the various federal states; 2000-2006 scores: Koller et al. (2000); 2007-2013 scores: Eckey (2008); treatment status: BAFA (2015);

Own calculation.

discussed in the introduction. They can be first discussed in the context of intraregional displacement effects. As mentioned in section 2.1, Bade and Alm (2010) find an annual employment growth rate for treated firms that exceeds those of

\footnotetext{
${ }^{13}$ The results for the 4 th and 5 th-order polynomials are reported in Table 7 , Part (II).
} 
the matched nontreated firms in the region. This suggests an intra-regional displacement effect: employment growth in the treated firms comes at the expense of comparable nontreated firms in the region. These insights might explore why we do not find any effect on regional employment growth, as our analysis captures intra-regional spillover effects.

Second, our results can also be interpreted in the context of the substitution of labour with capital. Our results point to the positive effect of the GRW on GVA growth. However, since we cannot report a significant employment effect, we can conclude that the positive output effect does not exceed the substitution effect (of labour by capital). In other words, an important target of the GRW - namely, the creation of jobs in economically weak regions - was not achieved in this period.

As stated above, in the second programming period (2007-2013), we find the GRW to have no significant effect at all. However, the findings for the second programming period cannot be interpreted without considering the global financial and economic crisis that took place during that time. Like most countries in the world, Germany set up very large short-term support programs to stabilize its economy. West German regions received about $€ 2$ billion in GRW grants during the 2007-2013 period; in contrast, the large fiscal stabilization schemes amounted to $€ 176$ billion in Germany (IWH 2015). ${ }^{14}$ The allocations of these support programs have nothing in common with the distribution of GRW funds. Given the smaller expenditures within the GRW framework, it is very likely that the identification of the effects of investment grants is distorted by these very large short-term programs.

\subsection{Considering inter-regional spillovers}

Since our analysis is conducted at a relatively small-scale regional level, we need to take into account potential interactions between a region and its neighbours. In doing so, it is possible to address inter-regional displacement effects. Regarding neighbours, we distinguish from nontreated regions those regions that were also treated within the GRW framework. The influence of mutual interactions may

\footnotetext{
${ }^{14}$ Data are reported only for Germany overall. There is no distinction made between the expenditures in East and West Germany, although the largest share has been spent in West Germany.
} 
differ between both categories. Whereas interactions with nontreated regions may have biased the effect of GRW subsidies in a supported region, the influence of other treated regions is not clear.

To control for inter-regional spillover, we introduce two dummy variables for each region in the regression model-namely, one for the existence of a treated neighbour, and one for the existence of a nontreated neighbour. The coefficients reported in Table 4 reveal no hint of an influence of inter-regional spillover, for neither treated nor nontreated regions.

Table 4: Estimation results including potential inter-regional spillovers

\begin{tabular}{|c|c|c|c|c|}
\hline & Employment & Wage sum & GVA & GVA/employee \\
\hline \multicolumn{5}{|c|}{ 2000-2006 programming period } \\
\hline \multirow[t]{2}{*}{ Treatment } & -0.00494 & -0.0159 & $0.0513^{* *}$ & $0.0567 * * *$ \\
\hline & $(0.0129)$ & $(0.0167)$ & $(0.0220)$ & $(0.0176)$ \\
\hline \multirow[t]{2}{*}{ Treated neighbour } & -0.00334 & -0.00760 & -0.00505 & -0.000923 \\
\hline & $(0.00550)$ & $(0.00813)$ & $(0.0119)$ & $(0.0107)$ \\
\hline \multirow[t]{2}{*}{ Nontreated neighbour } & 0.00566 & -0.0149 & 0.00368 & -0.00375 \\
\hline & $(0.00844)$ & $(0.0125)$ & $(0.0142)$ & $(0.0143)$ \\
\hline \multirow[t]{2}{*}{ Constant } & -0.00803 & $0.0571^{* * *}$ & $0.0856^{* * *}$ & $0.0950 * * *$ \\
\hline & $(0.0136)$ & $(0.0185)$ & $(0.0223)$ & $(0.0184)$ \\
\hline \multirow[t]{2}{*}{ adjusted $R^{2}$} & 0.143 & 0.226 & 0.0705 & 0.00772 \\
\hline & $2007-2013 p r$ & ogramming & eriod & \\
\hline \multirow{2}{*}{ Treatment } & 0.0152 & 0.0223 & -0.0109 & -0.0247 \\
\hline & $(0.0165)$ & $(0.0325)$ & $(0.0338)$ & $(0.0264)$ \\
\hline \multirow[t]{2}{*}{ Treated neighbour } & 0.00665 & 0.0133 & -0.00376 & -0.0112 \\
\hline & $(0.00706)$ & $(0.0142)$ & $(0.0145)$ & $(0.00969)$ \\
\hline \multirow[t]{2}{*}{ Nontreated neighbour } & -0.0186 & -0.0115 & -0.0265 & -0.00441 \\
\hline & $(0.0116)$ & $(0.0223)$ & $(0.0226)$ & $(0.0143)$ \\
\hline \multirow[t]{2}{*}{ Constant } & $0.0427 * * *$ & $0.159^{* * *}$ & $0.153^{* * *}$ & $0.104^{* * *}$ \\
\hline & $(0.0158)$ & $(0.0283)$ & $(0.0281)$ & $(0.0221)$ \\
\hline adjusted $R^{2}$ & 0.0781 & 0.0516 & 0.00255 & 0.0328 \\
\hline
\end{tabular}

Robust standard errors in parentheses; significance level: ${ }^{* * *} \mathrm{p}<0.01,{ }^{* *} \mathrm{p}<0.05,{ }^{*} \mathrm{p}<0.1$ Model specification: 3rd-order polynomial of the eligibility score; no constraints (coefficients omitted).

Sources: Statistical offices of the Federation and the various federal states; 2000-2006 scores: Koller et al. (2000); 2007-2013 scores: Eckey (2008); treatment status: BAFA (2015); matrix of neighbouring regions: BBSR. Own calculations. 


\subsection{The net effect of GRW subsidies}

In the next step, we assess the net effect of a $€ 1$ GRW subsidy, in a kind of economic efficiency calculation similar to that seen in Becker et al. (2010). ${ }^{15}$ This calculation provides some information on the efficiency of the program. We use the outcomes with significant treatment coefficients - namely, output and productivity growth in the first programming period. Table 5 summarizes the calculation steps.

Table 5: Effect of $€ 1$ GRW subsidy

\begin{tabular}{|c|c|c|}
\hline & GVA & GVA/employee \\
\hline Estimated coefficients & 0.0514 & 0.0561 \\
\hline Effect per annum & $0.86^{a}$ & $0.93^{a}$ \\
\hline Level values in 2000 & $3,350.87^{b}$ & $42,680.00^{c}$ \\
\hline Effect per annum in average region & $28.71^{b}$ & $0.0004^{c}$ \\
\hline Total GRW costs per annum & \multicolumn{2}{|c|}{$295,630^{b}$} \\
\hline Total GRW costs per annum per region & \multicolumn{2}{|c|}{$3,079^{b}$} \\
\hline Net effect (effect-costs ratio) per annum & $9.31^{d}$ & $1.29^{e}$ \\
\hline
\end{tabular}

The coefficients of the estimated influence of the GRW on growth of output (GVA) and productivity (GVA per employee) serve as the starting point. Regarding GVA, for instance, the coefficient is 0.0514 (column 3 in Table 3). This means that the GRW increased output growth by 5.14 percentage points. Hence, the average effect of the GRW on annual GVA growth is about 0.86 percentage points.

In 2000, the output level in the average treated region is about $€ 3.35$ billion (Table 2). As a consequence, GRW treatment causes the GVA to rise by about $€ 28.7$ million in a treated region. The total annual cost of GRW is about $€ 295.6$ million for all 96 treated regions, and about $€ 3.1$ million for the average treated region

\footnotetext{
${ }^{15}$ This calculation is based on three important assumptions (as discussed in footnote 28 of Becker et al. [2010, p. 589]). First, we must assume that all effects of the subsidies are visible until the end of the observation period. Second, the effect of the GRW is assumed to be homogeneous across regions. Third, we assume that $\mathrm{a} € 1$ cost is identical to a $€ 1$ GRW subsidy.
} 
(Table 1). In comparing the effect and the costs of the GRW for the average treated region, we may conclude that the net effect of GRW subsidies on output growth is about 9.31. In other words, $\mathrm{a} € 1$ expenditure for regional investment subsidies yields a $€ 9$ additional output per annum in the average treated region. Accordingly, the net effect of $€ 10,000$ regional investment subsidies on the growth of productivity (GVA per employee) is about $€ 1.29$ per annum in the average treated region.

\subsection{Robustness checks}

Beyond potential spillover to neighbouring regions, in this section, we more closely scrutinize our identification assumptions and the robustness of our results. First, we consider the regional control variables mentioned in section 4.2. To assess potential discontinuities in the controls, we use the estimation model. (See equations 1 and 2) to regress the controls on the eligibility score and examine whether these gaps are significantly different from zero (see Table 6.)

Reassuringly, we find no statistically significant coefficient for the eligibility score in any of the eight regressions.

Second, the validity of the estimation results depends on whether the chosen model provides an adequate description of the connection between the outcome and the forcing variable at the cut-off value (Angrist and Pischke 2009). We apply different strategies to check the sensitivity of the estimation results to potential deviations from the 'correct' model. In Table 7, we present results with respect to regional controls, different polynomial functions for the score, and different data ranges near the cut-off value. 


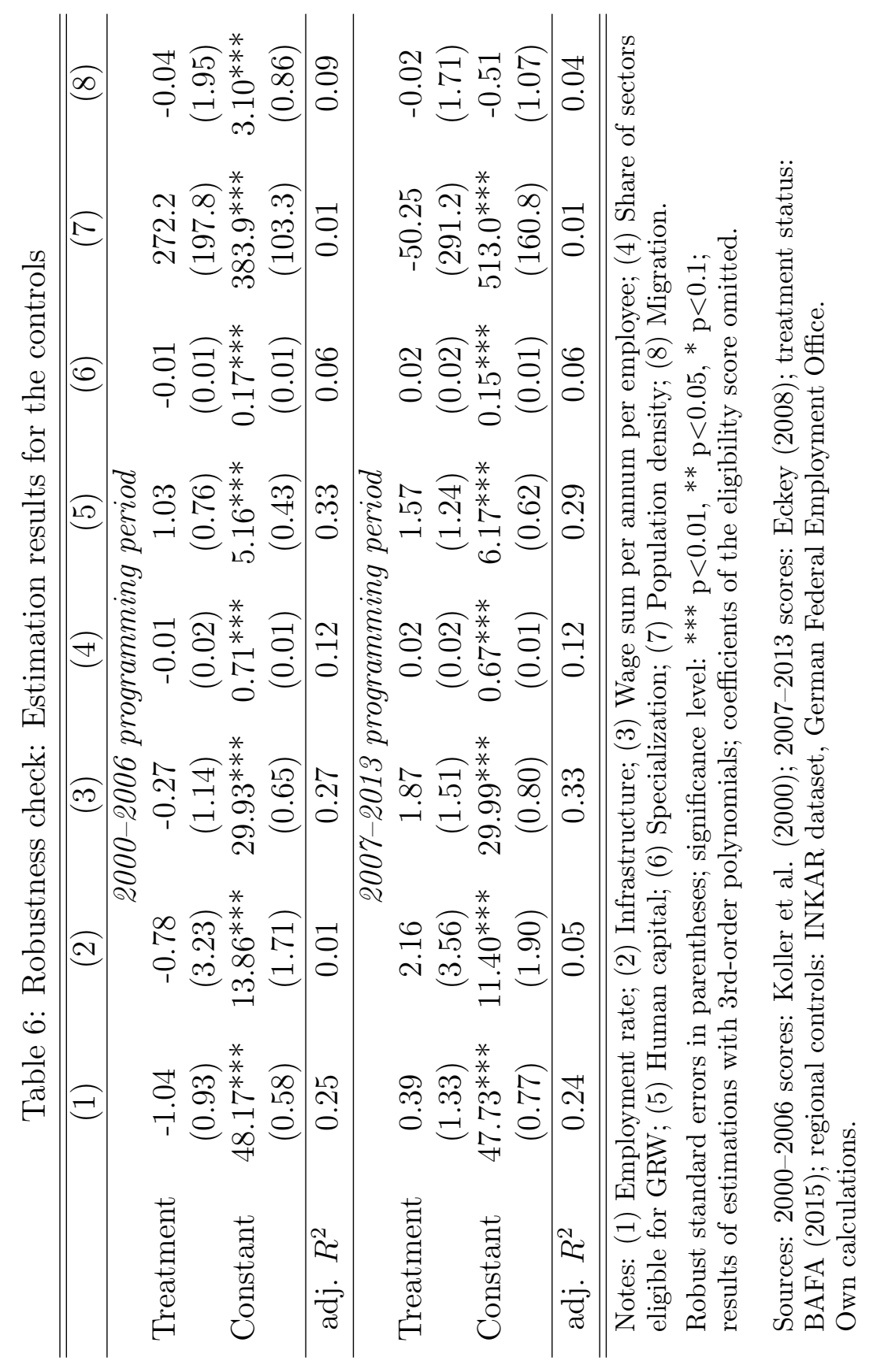


Part (I) of Table 7 presents the results for the regressions, if we were to include the aforementioned controls (equations 1 and 2 with a 3rd-order polynomial for the eligibility score). We find no change to the estimated treatment effects, for either the first or the second programming period. Full estimation results are given in Tables 9 and 10 of the Appendix. Part (II) of Table 7 shows robust results with respect to the choice of polynomial. Additionally, we restrict the value range of the eligibility score to around the cut-off value to contrast the regression approach with a local linear regression, as discussed in Lee and Lemieux (2010). The results are presented in Part (III) of Table 7. 
Table 7: Robustness check

\begin{tabular}{|c|c|c|c|c|}
\hline & Employment & Wage sum & GVA & GVA/employee \\
\hline \multicolumn{5}{|c|}{ (I) Estimation including controls } \\
\hline \multicolumn{5}{|c|}{ 2000-2006 programming period } \\
\hline Treatment & $\begin{array}{c}-0.00143 \\
(0.0120)\end{array}$ & $\begin{array}{l}-0.0120 \\
(0.0170)\end{array}$ & $\begin{array}{c}0.0549^{* *} \\
(0.0221)\end{array}$ & $\begin{array}{c}0.0558^{* * *} * \\
(0.0182)\end{array}$ \\
\hline Constant & $\begin{array}{c}0.164^{* * *} \\
(0.0596)\end{array}$ & $\begin{array}{c}0.101 \\
(0.0826)\end{array}$ & $\begin{array}{c}0.141 \\
(0.138)\end{array}$ & $\begin{array}{c}-0.0543 \\
(0.121)\end{array}$ \\
\hline adjusted $R^{2}$ & 0.287 & 0.279 & 0.103 & 0.0640 \\
\hline \multicolumn{5}{|c|}{ 2007-2013 programming period } \\
\hline Treatment & $\begin{array}{c}0.0163 \\
(0.0143)\end{array}$ & $\begin{array}{c}0.0337 \\
(0.0270)\end{array}$ & $\begin{array}{r}-0.00328 \\
(0.0323)\end{array}$ & $\begin{array}{l}-0.0191 \\
(0.0255)\end{array}$ \\
\hline Constant & $\begin{array}{l}-0.0947 \\
(0.0622)\end{array}$ & $\begin{array}{c}0.309^{* * *} \\
(0.116)\end{array}$ & $\begin{array}{c}0.135 \\
(0.111)\end{array}$ & $\begin{array}{c}0.241^{* * *} \\
(0.0858)\end{array}$ \\
\hline adjusted $R^{2}$ & 0.154 & 0.170 & 0.0771 & 0.109 \\
\hline
\end{tabular}

(II) Estimation using different polynomials

2000-2006 programming period

4th-order polynomial

\begin{tabular}{lcccc} 
Treatment & -0.0156 & -0.0247 & $0.0495^{* *}$ & $0.0669^{* * *}$ \\
Constant & $(0.0143)$ & $(0.0182)$ & $(0.0235)$ & $(0.0185)$ \\
& 0.00293 & $0.0420^{* * *}$ & $0.0891^{* * *}$ & $0.0856^{* * *}$ \\
& $(0.0108)$ & $(0.0127)$ & $(0.0163)$ & $(0.0128)$ \\
\hline adjusted $R^{2}$ & 0.148 & 0.220 & 0.0717 & 0.00680 \\
\hline \multicolumn{1}{c}{ 5th-order polynomial } & & & \\
Treatment & -0.0108 & -0.00813 & $0.0496^{* *}$ & $0.0625^{* * *}$ \\
& $(0.0145)$ & $(0.0199)$ & $(0.0231)$ & $(0.0198)$ \\
Constant & -0.00559 & $0.0351^{* * *}$ & $0.0816^{* * *}$ & $0.0874^{* * *}$ \\
& $(0.00915)$ & $(0.0113)$ & $(0.0152)$ & $(0.0120)$ \\
\hline adjusted $R^{2}$ & 0.174 & 0.224 & 0.0745 & 0.00244 \\
\hline
\end{tabular}

2007-2013 programming period

4th-order polynomial

\begin{tabular}{lcccc} 
Treatment & 0.0151 & 0.00957 & -0.0123 & -0.0280 \\
Constant & $(0.0122)$ & $(0.0224)$ & $(0.0269)$ & $(0.0229)$ \\
& $0.0316^{* * *}$ & $0.167^{* * *}$ & $0.127^{* * *}$ & $0.0925^{* * *}$ \\
& $(0.00921)$ & $(0.0139)$ & $(0.0162)$ & $(0.0150)$ \\
\hline adjusted $R^{2}$ & 0.0666 & 0.0592 & -0.00222 & 0.0290 \\
\hline \multicolumn{2}{c}{ 5th-order polynomial } & & & -0.0307 \\
Treatment & 0.0178 & 0.00357 & -0.0113 & $(0.0283)$ \\
& $(0.0146)$ & $(0.0272)$ & $(0.0345)$ & $0.0965^{* * *}$ \\
Constant & $0.0333^{* * *}$ & $0.180^{* * *}$ & $0.132^{* * *}$ & $(0.0169)$ \\
& $(0.0108)$ & $(0.0173)$ & $(0.0207)$ & 0.0257 \\
\hline adjusted $R^{2}$ & 0.0628 & 0.0809 & -0.00221 & continued on next page
\end{tabular}


Table 7 continued

\begin{tabular}{|c|c|c|c|c|}
\hline & Employment & Wage sum & GVA & GVA/employee \\
\hline \multicolumn{5}{|c|}{$\begin{array}{l}\text { (III) Estimation using varying bandwidths around the cut-off value } \\
\text { 2000-2006 programming period }\end{array}$} \\
\hline \multicolumn{5}{|c|}{ broad $\left(2^{*}\right.$ Standard deviation) } \\
\hline Treatment & $\begin{array}{l}-0.0115 \\
(0.0138)\end{array}$ & $\begin{array}{l}-0.0207 \\
(0.0175)\end{array}$ & $\begin{array}{c}0.0538^{* *} \\
(0.0223)\end{array}$ & $\begin{array}{c}0.0669^{* * *} \\
(0.0174)\end{array}$ \\
\hline Constant & $\begin{array}{c}-0.000773 \\
(0.0110)\end{array}$ & $\begin{array}{c}0.0407^{* * *} \\
(0.0135)\end{array}$ & $\begin{array}{c}0.0821^{* * *} \\
(0.0171)\end{array}$ & $\begin{array}{c}0.0825^{* * *} * \\
(0.0133)\end{array}$ \\
\hline adjusted $R^{2}$ & 0.121 & 0.182 & 0.0753 & 0.0138 \\
\hline Observations & 301 & 299 & 300 & 300 \\
\hline \multicolumn{5}{|c|}{ narrow (1* Standard deviation) } \\
\hline Treatment & $\begin{array}{c}-0.00654 \\
(0.0132)\end{array}$ & $\begin{array}{l}-0.0134 \\
(0.0175)\end{array}$ & $\begin{array}{c}0.0532^{* *} \\
(0.0220)\end{array}$ & $\begin{array}{c}0.0605^{* * *} \\
(0.0181)\end{array}$ \\
\hline Constant & $\begin{array}{l}-0.00736 \\
(0.00923)\end{array}$ & $\begin{array}{c}0.0349^{* * *} \\
(0.0113)\end{array}$ & $\begin{array}{c}0.0803^{* * *} \\
(0.0161)\end{array}$ & $\begin{array}{c}0.0883^{* * *} \\
(0.0122)\end{array}$ \\
\hline adjusted $R^{2}$ & 0.0458 & 0.0817 & 0.0505 & 0.0135 \\
\hline Observations & 201 & 201 & 201 & 201 \\
\hline \multicolumn{5}{|c|}{ data driven (excluding outliers) } \\
\hline Treatment & $\begin{array}{l}-0.0151 \\
(0.0151)\end{array}$ & $\begin{array}{l}-0.0184 \\
(0.0198)\end{array}$ & $\begin{array}{c}0.0470 * * \\
(0.0235)\end{array}$ & $\begin{array}{c}0.0635^{* * *} \\
(0.0198)\end{array}$ \\
\hline Constant & $\begin{array}{l}-0.00436 \\
(0.00992)\end{array}$ & $\begin{array}{c}0.0359^{* * *} \\
(0.0121)\end{array}$ & $\begin{array}{c}0.0782^{* * *} \\
(0.0161)\end{array}$ & $\begin{array}{c}0.0830^{* * *} \\
(0.0134)\end{array}$ \\
\hline adjusted $R^{2}$ & 0.0985 & 0.159 & 0.113 & 0.0274 \\
\hline Observations & 251 & 249 & 250 & 250 \\
\hline \multicolumn{5}{|c|}{ 2007-2013 programming period } \\
\hline \multicolumn{5}{|c|}{ broad (2* Standard deviation) } \\
\hline Treatment & $\begin{array}{c}0.0228 \\
(0.0159)\end{array}$ & $\begin{array}{c}0.0308 \\
(0.0297)\end{array}$ & $\begin{array}{c}0.000859 \\
(0.0312)\end{array}$ & $\begin{array}{l}-0.0236 \\
(0.0249)\end{array}$ \\
\hline Constant & $\begin{array}{l}0.0286^{* *} \\
(0.0119)\end{array}$ & $\begin{array}{l}0.158^{* * * *} \\
(0.0176)\end{array}$ & $\begin{array}{l}0.122^{* * *} \\
(0.0186)\end{array}$ & $\begin{array}{c}0.0909^{* * *} \\
(0.0156)\end{array}$ \\
\hline adjusted $R^{2}$ & 0.0554 & 0.0645 & 0.0282 & 0.00435 \\
\hline Observations & 298 & 296 & 297 & 297 \\
\hline \multicolumn{5}{|c|}{ narrow (1* Standard deviation) } \\
\hline Treatment & $\begin{array}{c}0.0304^{* *} \\
(0.0153)\end{array}$ & $\begin{array}{c}0.0323 \\
(0.0287)\end{array}$ & $\begin{array}{l}0.00189 \\
(0.0341)\end{array}$ & $\begin{array}{l}-0.0305 \\
(0.0280)\end{array}$ \\
\hline Constant & $\begin{array}{l}0.0264^{* *} \\
(0.0112)\end{array}$ & $\begin{array}{l}0.166^{* * *} \\
(0.0178)\end{array}$ & $\begin{array}{l}0.125^{* * *} \\
(0.0211)\end{array}$ & $\begin{array}{c}0.0965^{* * *} \\
(0.0169)\end{array}$ \\
\hline adjusted $R^{2}$ & -0.0361 & 0.0390 & -0.0142 & -0.00665 \\
\hline Observations & 209 & 207 & 208 & 208 \\
\hline \multicolumn{5}{|c|}{ data driven (excluding outliers) } \\
\hline Treatment & $\begin{array}{l}0.0321^{* *} \\
(0.0161)\end{array}$ & $\begin{array}{c}0.0322 \\
(0.0304)\end{array}$ & $\begin{array}{c}0.0136 \\
(0.0366)\end{array}$ & $\begin{array}{l}-0.0216 \\
(0.0297)\end{array}$ \\
\hline
\end{tabular}


Table 7 continued

\begin{tabular}{lcccc}
\hline \hline & Employment & Wage sum & GVA & GVA/employee \\
\hline Constant & $0.0236^{* *}$ & $0.159^{* * *}$ & $0.116^{* * *}$ & $0.0906^{* * *}$ \\
& $(0.0119)$ & $(0.0188)$ & $(0.0220)$ & $(0.0178)$ \\
\hline adjusted $R^{2}$ & -0.0565 & -0.0234 & -0.0165 & 0.00819 \\
Observations & 229 & 227 & 228 & 228 \\
\hline \hline Robust standard errors in parentheses; significance level: ${ }^{* * *} \mathrm{p}<0.01,{ }^{* *} \mathrm{p}<0.05,{ }^{*} \mathrm{p}<0.1$ \\
Model specification for I and III: 3rd-order polynomial of the eligibility score, no constraints \\
(coefficients omitted).
\end{tabular}

In a relatively broad bandwidth, we include all regions within the double standard deviation around the cut-off value (including score values between 98.11 and 100.85 for the first programming period, and between 99.089 and 100.95 for the second). A narrow bandwidth defines the data range according to the standard deviation around the cut-off value (including score values of 98.79-100.17 and 99.56-100.49, respectively). A third bandwidth excludes the 'outliers' at the boundaries, resulting in data ranges of 98.9-100.55 and 99.55-100.55 for the first and second programming periods, respectively. Here, we find that the results are very similar to those from the whole sample. In summary, the results of the reliability and robustness checks provide strong evidence of the validity of our identification strategy.

\section{Summary and conclusion}

This study explored the causal effects of the most important regional policy scheme in Germany. The GRW provides grants for discretionary investment in economically lagging regions, to trigger their development. The overarching goal of this program is the reduction of regional disparities among German regions. To identify whether the GRW works in line with its stated goals, we used discontinuities in the treatment probability triggered by EU legislatives.

The analysis focused on West German regions and the 2000-2006 and 2007-2013 programming periods. We found a positive effect of regional investment subsidies on the growth of GVA and productivity, by about 5 percentage points, for the entire 2000-2006 programming period. However, we found them to have no effect on growth in regional employment or wages in this period. These results can be 
associated with two theoretical considerations. First, a plant-level study by Bade and Alm (2010) reports positive employment growth rates for GRW-treated firms, but also negative ones for comparable nontreated firms within the same region. This finding points to intra-regional displacement effects that are confirmed by our study for the whole of the regional economy. Second, the investment support scheme obviously improved the competitiveness of those treated regions close to the eligibility cut-off value. However, these regions were not able to transform their gains in competitiveness into significant employment growth. This finding aligns with some theoretical considerations, where investment support schemes change on account of substituting labour with capital.

Finally, we estimated the net effect of this program for the first programming period under analysis. We find that each $€ 1$ of expenditures in regional investment subsidies yield an additional $€ 9.3$ of output per annum in the average treated region. Accordingly, the net effect of $€ 10,000$ regional investment subsidies on the growth of output per worker is about $€ 1.3$ per annum in the average treated region.

Regarding the 2007-2013 programming period, the results are not at all significant. We attribute this result to massive governmental interventions made to stabilize the German economy in the aftermath of the financial crisis during that period. Total expenditures for these short-term programs amounted to $€ 176$ billion while only $€ 2$ billion were spent within the regional investment program framework. It is very likely that the effects of these very large programs supplanted or otherwise distorted the effect of the GRW. 


\section{References}

Angrist, J. D. and J.-S. Pischke (2009): Mostly Harmless Econometrics. Princeton, New Jersey: Princeton University Press. BA, German Federal Employment Office: Employment Statistics.

Bade, F.-J. (2013): Bedeutung und Wirksamkeit der Foerderung groesserer Unternehmen durch den gewerblichen Investitionszuschuss im Rahmen der Gemeinschaftsaufgabe "Verbesserung der regionalen Wirtschaftsstruktur" (GRW). Tech. rep. BMWi.

Bade, F.-J. and B. Alm (2010): Endbericht zum Gutachten Evaluierung der Gemeinschaftsaufgabe Verbesserung der regionalen Wirtschaftsstruktur (GRW) durch einzelbetriebliche Erfolgskontrolle fuer den Foerderungszeitraum 1999-2008 und Schaffung eines Systems fuer ein gleitendes Monitoring. BMWi Research Report. access: 201501-07. Bundeswirtschaftsministerium.

url: http://www.bmwi.de/DE/Mediathek/Publikationen/publikationenarchiv, $\operatorname{did}=376256$. html.

BAFA, German Federal Office for Economic Affairs and Export Control (2015): Statistik der Gemeinschaftsaufgabe "Verbesserung der regionalen Wirtschaftsstruktur", Bewilligungsbescheide seit 1991, Eschborn, den 8.6.2015.

Becker S., Egger P. and M. von Ehrlich (2013): Absorptive capacity and the growth and investment effects of regional transfers: a regression discontinuity design with heterogeneous treatment effects. In: American Economic Journal: Policy 5, pp. 29-77.

Becker, S., Egger P. and M. von Ehrlich (2012): Too much of a good thing? On the growth effects of the EU"s regional policy. In: European Economic Review 56, pp. 648-668.

Becker, S., Egger, P. and M. von Ehrlich (2010): Going NUTS: the effect of EU Structural Funds on regional performance. In: Journal of Public Economics 94, 9-10, pp. 578-590.

Bernini, C. and G. Pellegrini (2011): How are growth and productivity in private firms affected by public subsidy? Evidence from a regional policy. In: Regional Science and Urban Economics 41, pp. 253-265.

Bronzini, R. and G. de Blasio (2006): Evaluating the impact of investment incentives: The case of Italy"s Law 488/1992. In: Journal of Urban Economics 60, pp. 327-349.

Castris, M. de and G. Pellegrini (2012): Evaluation of Spatial Effects of Capital Subsidies in the South of Italy. In: Regional Studies 46, pp. 525-538.

Cerqua, A. and G. Pellegrini (2014): Do subsidies to private capital boost firms' growth? A multiple regression discontinuity design approach. In: Journal of Public Economics 109, pp. 114-126. 
Ciani, E. and G. de Blasio (2015): European structural funds during the crisis: Evidence from Southern Italy. IZA Journal of Labor Policy 4: 20.

Criscuolo, C., Martin, R., Overman, H. and J. van Reenen (2012): The causal effect of an industrial policy. NBER Working Paper 17842. Cambridge: National Bureau of Economic Research.

Criscuolo, C., R. Martin, H. Overman, and J. van Reenen (2016): The Causal Effects of an Industrial Policy. CEP Discussion Paper No 1113.

Devereux, M., Griffith, R. and H. Simpson (2007): Firm location decisions, regional grants and agglomeration externalities. In: Journal of Public Economics 91, pp. 413-435.

Eckey, H.-F. (2008): Verbesserung der regionalen Wirtschaftsstruktur. Gesetz ueber die Gemeinschaftsaufgabe vom 6. Oktober 1969. In: Handbuch der regionalen Wirtschaftsoerderung. Ed. by H. H. Eberstein, H. Karl, and G. Untiedt. Vol. 1. Koeln: Otto Schmidt Verlag. Chap. V.

Ehrlich, M. v. and T. Seidel (2015): The Persistent Effects of Place-Based Policy: Evidence from the West-German Zonenrandgebiet. CESifo Working Paper No. 5373 (May 2015).

Falck, O., Heblich, S. and S. Kipar (2010): Industrial innovation: direct evidence from a cluster-orientated policy. In: Regional Science and Urban Economics 40, pp. 574-582.

Glaeser, E., Gottlieb, J. (2008): The economics of place-making policies. Brookings Papers on Economic Activity, Spring, pp. 155-239.

GRW-law, Bundesregierung (1969): Gesetz ueber die Gemeinschaftsaufgabe "Verbesserung der regionalen Wirtschaftsstruktur" (GRW-Gesetz). Bundesgesetzblatt I p. 1861. zuletzt geaendert 2007 (BGBl I S. 2246).

Hahn, J., P. Todd, and W. van der Klaauw (2001): Identification and Estimation of Treatment Effects with a Regression-Discontinuity Design. In: Econometrica 69, pp. 201-209.

Imbens, G. W. and T. Lemieux (2008): Regression discontinuity designs: A guide to practice. In: Journal of Econometrics 142, pp. 615-635.

IWH, Leibniz-Institut fuer Wirtschaftsforschung Halle (IWH), Kiel Economics (ed.) (2015): Oekonomische Wirksamkeit der konjunkturstuetzenden finanzpolitischen Massnahmen der Jahre 2008 und 2009. Forschungsvorhaben im Auftrag des Bundesministeriums der Finanzen. IWH Online 4/2015. Halle (Saale).

Kline, P. and E. Moretti (2014a): People, places and public policy. Some simple welfare economics if local economic development programs. In: Annual Review of Economics 6, pp. 629-662.

Kline, P. and E. Moretti (2014b): Local economic development, agglomeration economies, and the big push: 100 years of evidence from the Tennessee Valley Authority. In: Quarterly Journal of Economics 129, pp. 275-331. 
Klodt, H. (2000): Industrial Policy and the East German Productivity Puzzle. In: German Economic Review 1(3), pp. 315-333.

Koller, M., Schiebel, W. and B. Schwengler (2000): Neuberechnung der Regionalindikatoren zur Neuabgrenzung der Foerdergebiete ("Gemeinschaftsaufgabe Verbesserung der regionalen Wirtschaftsstruktur"). Project Number 502. Policy Consulting Report.

Lee, D. S. and T. Lemieux (2010): Regression Discontinuity Design in Economics. In: Journal of Economic Literature 48, pp. 281-355.

Martin, P., Mayer, T. and F. Mayneris (2011): Public support to clusters. A firm level study of French Local Productive Systems. In: Regional Science and Urban Economics 41, pp. 108-123.

Mayer, T., Mayneris, F. and L. Py (2015): The impact of Urban Enterprise Zones on establishment location decision and labor market outcomes: evidence from France. In: Journal of Economic Geography (forthcoming).

McCrary, J. (2008): Manipulation of the running variable in the regression discontinuity design: A density test. In: Journal of Econometrics 142, pp. 698-714.

Moretti, E. (2010): Local Labor Markets. In: Card, D., Ashenfelter, O. (Eds.), Handbook of Labor Economics, Volume 4B. Elsevier, Amsterdam.

Neumark, D. and J. Kolko (2010): Do enterprise zones create jobs? Evidence from California"s enterprise zone program. In: Journal of Urban Economics 68, pp. 1-19.

Neumark, D. and H. Simpson (2014): Place-Based Policies. NBER Working Paper 20049 .

Pellegrini, G. and M. Cetra (2006): Growth and efficiency in subsidized firms. Paper prepared for the Workshop 'The Evaluation of Labour Market, Welfare and Firms Incentives Programmes", May 11th - 13th 2006, Istituto Veneto di Scienze, Lettere ed Arti. Venezia.

Schwengler, B. and J. Binder (2006): Solutions for the weighting problem of regional aid indicators when changing to one model for Germany. In: Raumforschung und Raumordnung 4, pp. 284-298.

Stierwald, A. and J. Wiemers (2003): Auswirkungen der Gemeinschaftsaufgabe zur "Verbesserung der regionalen Wirtschaftsstruktur" auf die Investitionsfaehigkeit. Eine einzelwirtschaftliche Wirkungsanalyse fuer Betriebe des Verarbeitendes Gewerbes in Ostdeutschland. Diskussionspapier 185. Institut fuer Wirtschaftsforschung Halle.

Wooldridge, J. M. (2010): Econometric Analysis of Cross Section and Panel Data. 2nd. Cambridge, Massachusetts: MIT Press. 


\section{Appendix}

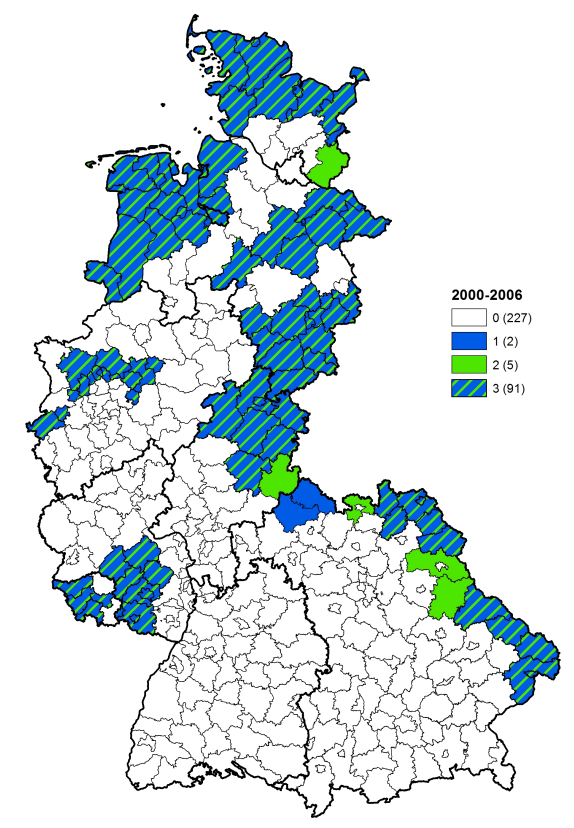

2000-2006 programming period

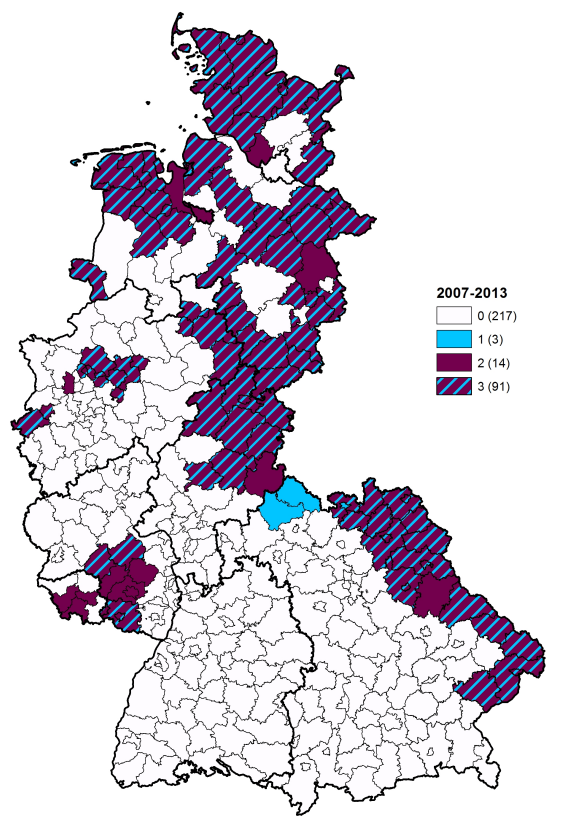

2007-2013 programming period

Figure 7: Spatial allocation of the different types of regions

Notes: Figures in parentheses pertain to the number of regions. Type $=0$ : assignment status $=$ treatment status $=0$; Type 1: assignment status $=1$, treatment status $=0$; Type 2 : assignment status $=0$, treatment status $=1$; Type 3 : assignment status $=$ treatment status $=1$.

Sources: 2000-2006 scores: Koller et al. (2000); 2007-2013 scores: Eckey (2008); eligibility status: coordination frameworks (see Table 11); treatment status: BAFA (2015). Own illustration. 
Table 8: Descriptive statistics of control variables

\begin{tabular}{|c|c|c|c|c|c|c|}
\hline & \multicolumn{3}{|c|}{ Nontreated regions } & \multicolumn{3}{|c|}{ Treated regions } \\
\hline & Mean & Min & Max & Mean & Min & $\operatorname{Max}$ \\
\hline \multicolumn{7}{|c|}{ Level values 1999} \\
\hline Employment rate & 49.71 & 38.80 & 55.10 & 46.62 & 39.20 & 56.70 \\
\hline Infrastructure ${ }^{(1)}$ & 12.41 & 0.40 & 43.09 & 14.60 & 1.32 & 66.68 \\
\hline Wage per employee ${ }^{(2)}$ & 31.83 & 23.32 & 43.90 & 29.14 & 21.59 & 49.34 \\
\hline Economic structure ${ }^{(3)}$ & 7.71 & 3.00 & 22.80 & 5.35 & 2.70 & 11.80 \\
\hline Human capital ${ }^{(4)}$ & 0.73 & 0.52 & 0.89 & 0.69 & 0.55 & 0.89 \\
\hline Specialization $^{(5)}$ & 0.18 & 0.10 & 0.48 & 0.16 & 0.10 & 0.41 \\
\hline Population density & 590.60 & 77.47 & 3847.58 & 510.65 & 42.71 & 3416.84 \\
\hline Migration & 4.30 & -15.40 & 18.40 & 2.26 & -13.60 & 13.70 \\
\hline Observations & \multicolumn{3}{|c|}{229} & \multicolumn{3}{|c|}{96} \\
\hline \multicolumn{7}{|c|}{ Level values 2006} \\
\hline Employment rate & 49.85 & 36.50 & 56.10 & 46.18 & 38.90 & 55.40 \\
\hline Infrastructure ${ }^{(1)}$ & 12.14 & 0.40 & 41.15 & 13.91 & 1.32 & 64.29 \\
\hline Wage per employee ${ }^{(2)}$ & 33.51 & 22.44 & 53.21 & 30.35 & 21.39 & 41.08 \\
\hline Economic structure ${ }^{(3)}$ & 8.92 & 3.60 & 27.20 & 6.44 & 3.30 & 16.80 \\
\hline Human capital ${ }^{(4)}$ & 0.71 & 0.50 & 0.89 & 0.66 & 0.48 & 0.84 \\
\hline Specialization $^{(5)}$ & 0.18 & 0.09 & 0.48 & 0.15 & 0.11 & 0.34 \\
\hline Population density ${ }^{(6)}$ & 580.44 & 58.67 & 4169.83 & 534.83 & 41.72 & 3306.57 \\
\hline Migration $^{(7)}$ & 0.58 & -20.80 & 36.30 & -1.12 & -9.30 & 8.00 \\
\hline Observations & \multicolumn{3}{|c|}{220} & \multicolumn{3}{|c|}{105} \\
\hline
\end{tabular}

Notes: ${ }^{(1)}$ Travel time to next motorway, in minutes; ${ }^{(2)} €$ Thousands; ${ }^{(3)}$ share of sectors eligible to GRW subsidies; ${ }^{(4)}$ share of highly qualified employees; ${ }^{(5)}$ Herfindahl Index; ${ }^{(6)}$ inhabitants per square $\mathrm{km} ;{ }^{(7)}$ net migration per 1,000 inhabitants.

Sources: INKAR dataset, German Federal Employment Office; BAFA (2015). Own calculations. 
Table 9: Estimation results including control variables (2000-2006)

\begin{tabular}{lcccc}
\hline \hline & Employment & Wage sum & GVA & GVA/employee \\
\hline Treatment & -0.00143 & -0.0120 & $0.0549^{* *}$ & $0.0558^{* * *}$ \\
Employment & $(0.0120)$ & $(0.0170)$ & $(0.0221)$ & $(0.0182)$ \\
& $-0.00285^{* * *}$ & $-0.00406^{* * *}$ & $-0.00461^{* *}$ & -0.00125 \\
Infrastructure & $(0.00100)$ & $(0.00157)$ & $(0.00225)$ & $(0.00182)$ \\
& $-0.000875^{* * *}$ & $-0.000781^{*}$ & -0.000424 & 0.000593 \\
Wage/employee & $(0.000248)$ & $(0.000417)$ & $(0.000585)$ & $(0.000436)$ \\
Human capital & -0.000818 & $0.00275^{* *}$ & 0.00157 & 0.00235 \\
& $(0.00134)$ & $(0.00138)$ & $(0.00217)$ & $(0.00261)$ \\
Economic structure & 0.00104 & 0.000520 & -0.000693 & -0.00165 \\
Specialization & $(0.00124)$ & $(0.00178)$ & $(0.00259)$ & $(0.00224)$ \\
& 0.0114 & 0.0710 & 0.147 & 0.147 \\
Pop. density & $(0.0711)$ & $(0.100)$ & $(0.146)$ & $(0.109)$ \\
Migration & -0.0563 & 0.0729 & 0.0975 & 0.143 \\
& $(0.0763)$ & $(0.119)$ & $(0.245)$ & $(0.195)$ \\
Constant & $-1.49 \mathrm{e}-05^{* * *}$ & $-2.24 \mathrm{e}-05^{* * *}$ & $-7.43 \mathrm{e}-06$ & $9.18 \mathrm{e}-06$ \\
& $(3.90 \mathrm{e}-06)$ & $(5.71 \mathrm{e}-06)$ & $(8.53 \mathrm{e}-06)$ & $(7.79 \mathrm{e}-06)$ \\
& $0.00110^{*}$ & 0.00119 & $0.00300^{* *}$ & 0.00165 \\
adjusted $R^{2}$ & $(0.000572)$ & $(0.000827)$ & $(0.00141)$ & $(0.00117)$ \\
\hline \hline
\end{tabular}

Notes: Robust standard errors in parentheses; significance level: ${ }^{* * *} \mathrm{p}<0.01,{ }^{* *} \mathrm{p}<0.05,{ }^{*} \mathrm{p}<0.1$

Model specification: 3rd-order polynomial of the eligibility score; no constraints (coefficients omitted).

Sources: Scores: Koller et al. (2000); treatment status: BAFA (2015); regional controls: INKAR dataset, German Federal Employment Office. Own calculations. 
Table 10: Estimation results including control variables (2007-2013)

\begin{tabular}{lcccc}
\hline \hline & Employment & Wage sum & GVA & GVA/employee \\
\hline Treatment & 0.0163 & 0.0337 & -0.00328 & -0.0191 \\
Employment & $(0.0143)$ & $(0.0270)$ & $(0.0323)$ & $(0.0255)$ \\
& $-8.44 \mathrm{e}-05$ & -0.000241 & 0.00179 & 0.00179 \\
Infrastructure & $(0.000998)$ & $(0.00176)$ & $(0.00189)$ & $(0.00144)$ \\
& $-9.84 \mathrm{e}-05$ & $-0.00114^{* *}$ & -0.000630 & -0.000460 \\
Wage/employee & $(0.000274)$ & $(0.000546)$ & $(0.000501)$ & $(0.000389)$ \\
Human capital & 0.000854 & $-0.00736^{* *}$ & 0.000191 & -0.000900 \\
& $(0.00135)$ & $(0.00293)$ & $(0.00235)$ & $(0.00133)$ \\
Economic structure & 0.000789 & 0.00127 & $-0.00453^{* *}$ & $-0.00515^{* * *}$ \\
Specialization & $(0.00117)$ & $(0.00223)$ & $(0.00224)$ & $(0.00177)$ \\
& $\left(0.179^{* * *}\right.$ & 0.102 & -0.116 & $-0.301^{* * *}$ \\
Pop. density & -0.0946 & $(0.128)$ & $(0.118)$ & $(0.0885)$ \\
Migration & $(0.0941)$ & 0.171 & 0.183 & $0.262^{*}$ \\
& $-1.21 \mathrm{e}-05^{* * *}$ & $-3.82 \mathrm{e}-06$ & $-2.18 \mathrm{e}-05^{* *}$ & $(0.139)$ \\
Constant & $(4.38 \mathrm{e}-06)$ & $(8.33 \mathrm{e}-06)$ & $(9.46 \mathrm{e}-06)$ & $-7.85 \mathrm{e}-06$ \\
& $0.00273^{* * *}$ & $0.00473^{* * *}$ & $0.00467^{* * *}$ & $0.00158^{*}$ \\
& $(0.000968)$ & $(0.00157)$ & $(0.00159)$ & $(0.000884)$ \\
adjusted $R^{2}$ & -0.0947 & $0.309^{* * *}$ & 0.135 & $0.241^{* * *}$ \\
\hline \hline
\end{tabular}

Notes: Robust standard errors in parentheses; significance level: ${ }^{* * *} \mathrm{p}<0.01,{ }^{* *} \mathrm{p}<0.05,{ }^{*} \mathrm{p}<0.1$ Model specification: 3rd-order polynomial of the eligibility score; no constraints (coefficients omitted).

Sources: Scores: Eckey (2008); treatment status: BAFA (2015); regional controls: INKAR dataset, German Federal Employment Office. Own calculations. 
Table 11: Relevant coordination frameworks (legal documents)

\begin{tabular}{lccc}
\hline \hline Coordination framework & $\begin{array}{c}\text { Bundestags-Drucksache } \\
\text { (reference number) }\end{array}$ & Publication date & Period \\
\hline 22. Rahmenplan & $12 / 4850$ & $19-05-1993$ & $1993-1996(1997)$ \\
23. Rahmenplan & $12 / 7175$ & & $1994-1997(1998)$ \\
24. Rahmenplan & $13 / 1376$ & $16-05-1995$ & $1995-1998(1999)$ \\
25. Rahmenplan & $13 / 4291$ & $09-04-1996$ & $1996-1999(2000)$ \\
26. Rahmenplan & $13 / 7205$ & $13-03-1997$ & $1997-2000(2001)$ \\
27. Rahmenplan & $13 / 9992$ & $27-02-1998$ & $1998-2001(2002)$ \\
28. Rahmenplan & $14 / 776$ & $19-04-1999$ & $1999-2002(2003)$ \\
29. Rahmenplan & $14 / 3250$ & & $2000-2003(2004)$ \\
30. Rahmenplan & $14 / 5600$ & $12-03-2001$ & $2001-2004(2005)$ \\
31. Rahmenplan & $14 / 8463$ & $06-03-2002$ & $2002-2005$ \\
32. Rahmenplan & $15 / 861$ & $10-04-2003$ & $2003-2006$ \\
33. Rahmenplan & $15 / 2961$ & $22-04-2004$ & $2004-2007$ \\
34. Rahmenplan & $15 / 5141$ & $14-03-2005$ & $2005-2008$ \\
35. Rahmenplan & $16 / 1790$ & $07-06-2006$ & $2006-2009$ \\
36. Rahmenplan & $16 / 5215$ & $27-04-2007$ & $2007-2010$ \\
Koordinierungsrahmen & $16 / 13950$ & $08-09-2009$ & from 2009 \\
\hline \hline
\end{tabular}

Note: All documents are available at the following homepage: http://pdok.bundestag.de/.

Source: Own compilation and illustration. 